\title{
26. SITE SURVEYS IN THE WESTERN PACIFIC CONDUCTED ABOARD THE KANA KEOKI, CRUISE KK810626 LEG $4^{1}$
}

\author{
Lisa D. Petersen and Fred K. Duennebier, Hawaii Institute of Geophysics, University of Hawaii \\ and \\ Thomas H. Shipley, Institute for Geophysics, University of Texas, Austin ${ }^{2}$
}

\begin{abstract}
In preparation for Deep Sea Drilling Project Leg 89, the Kana Keoki of the Hawaii Institute of Geophysics surveyed possible drilling sites in the western Pacific in the fall of 1981. Two of the sites surveyed are in the eastern part of the Mariana Basin, where we hoped to find a thick sediment section, lacking Cretaceous sills or flows, overlying a deep basement, for the Glomar Challenger to drill to the oldest Pacific crust. Site MZP-6 (Deep Sea Drilling Project [DSDP] Site 585) is in a small basin, east of DSDP Site 199, containing about $1000 \mathrm{~m}$ of sediments apparently undisturbed by Cretaceous volcanism. Analysis of our seismic data suggested that oceanic basement of unknown age lies at $7100 \mathrm{~m}$ below sea level. This site had the thickest sediment section and the deepest basement of all the areas we surveyed, and we therefore recommended this basin for drilling on Leg 89. Site MZP-3 is a basin located immediately to the east of MZP-6. Sediment cover in the MZP-3 region averages only $0.4 \mathrm{~s}$ thickness, and an undulatory basement lies at about $6000 \mathrm{~m}$ below sea level. Our detailed survey revealed several WNW-trending ridges about $600 \mathrm{~m}$ high and $8 \mathrm{~km}$ across. More investigation in this region is necessary to explain the differences between the MZP-6 and MZP-3 sites.

Two seamounts were surveyed for possible drilling in the future. Seamount 853 , located about $365 \mathrm{~km}$ east-southeast of Guam, has a thick reef cap, probably Cretaceous. Drilling of Seamount 853 may show that it was formed during the Cretaceous volcanic event or affected by the associated uplift. Sylvania Guyot, adjacent to Bikini Atoll, is a flat-topped seamount with approximately $285 \mathrm{~m}$ of sediment overlying basement. Future drilling could reveal the subsidence history of Sylvania and explain why it became a guyot but Bikini became an atoll.
\end{abstract}

\section{INTRODUCTION}

It has been believed for many years that the oldest Pacific crust lies somewhere in the western Pacific, probably in the Mariana Basin (Larson and Chase, 1972). Previous attempts to drill to the ocean crust have been unsuccessful in the Mariana Basin, but another attempt was planned by Leg 89 scientists in 1982 .

Four possible drilling sites were surveyed by the Hawaii Institute of Geophysics vessel Kana Keoki between Guam and Majuro in the fall of 1981. Two sites were in the eastern part of the Mariana Basin: one at DSDP Site 199 and the other at a small basin immediately east of the Site 199 area. Our objective in these basinal areas was to obtain clear seismic reflection records with penetration through the sediments to basement, and to locate sediment sections lacking Cretaceous sills or flows (Fig. 1). The other two sites were seamounts: one east of Guam, believed to be Cretaceous or older, and Sylvania Guyot (adjacent to Bikini Atoll), whose origin is yet unexplained. These seamounts may be drilled in the future.

The track of Kana Keoki cruise KK810626 Leg 4 is shown in Figure 1. In addition to the collection of underway bathymetry, magnetics, and gravity data, singlechannel seismic reflection profiles were obtained over about $80 \%$ of the track using two 80 -in ${ }^{3}$ water guns. All

\footnotetext{
${ }^{1}$ Moberly, R., Schlanger, S. O., et al., Init. Repts. DSDP, 89: Washington (U.S. Govt. Printing Office).

2 Addresses: (Petersen and Duennebier) Hawaii Institute of Geophysics, University of Hawaii, 2525 Correa Road, Honolulu, HI 96822; (Shipley) Institute for Geophysics, University of Texas, Austin, TX 78712 .
}

of the seismic data, including those from 22 sonobuoy stations, were recorded and processed digitally under a separate contract to Scripps Institution of Oceanography (SIO). Four piston cores and two dredge hauls also were recovered. In addition to data collected during our site surveys, all available data collected previously by various institutions have been gathered and incorporated into our maps and report.

\section{REGIONAL GEOLOGY}

The age of the Pacific Ocean floor west of Hawaii is generally believed be Cretaceous and older (Larson and Chase, 1972). When Larson and Chase (1972) correlated the Japanese, Phoenix, and Hawaiian magnetic lineations, they postulated that the region east of the Mariana Trench was the oldest crust in the Pacific basin and inferred an age of early Jurassic or older. This region, known as the Mariana Basin, was apparently formed during the Jurassic magnetic quiet interval, so the seafloor spreading history for the region is difficult to interpret.

More information has been revealed on magnetic anomalies in the western Pacific since the work of Larson and Chase (1972) (Fig. 1). The Phoenix lineations, originally identified as M1 to M10 anomalies trending eastward, have now been identified to M14 (Larson, 1976). Anomalies M11 to M25 just east of the Marshall-Gilbert Islands, later extended by Cande et al. (1978) to M29, have also been identified. Magnetic anomalies in the Nauru Basin trending northeast have been identified as M16 to M29 (Larson, 1976; Cande et al., 1978). The Hawaiian lineation identifications have remained un- 
A

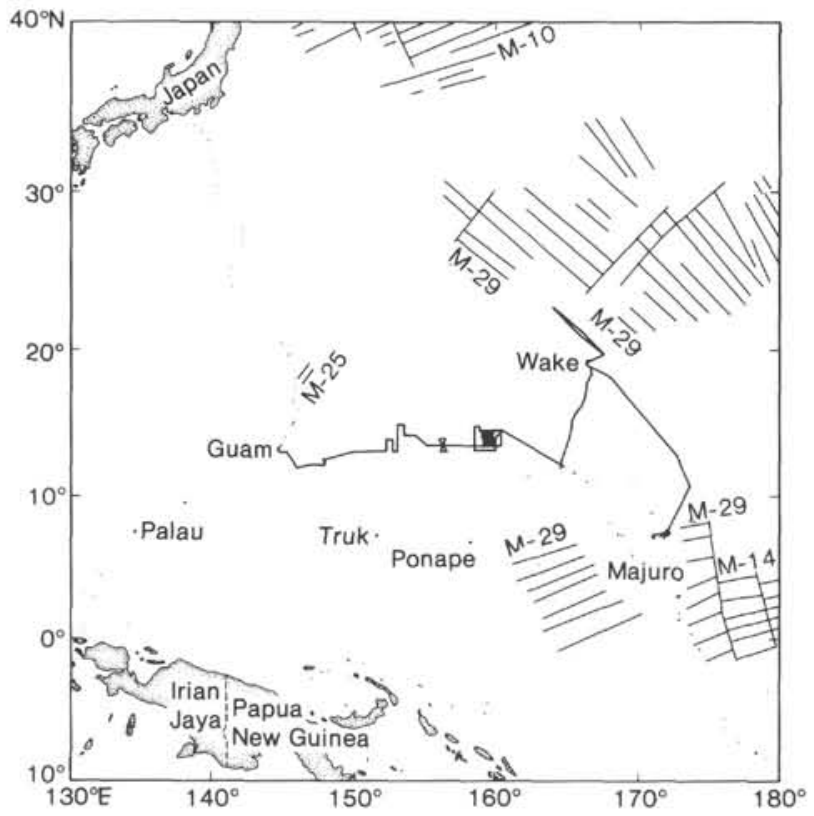

B

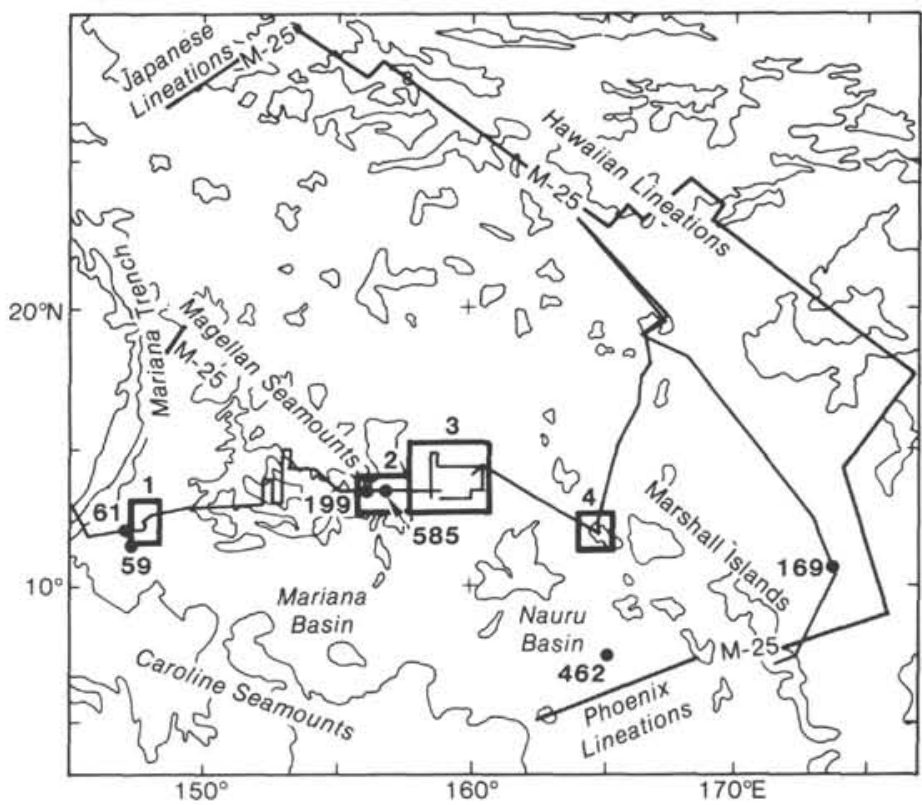

Figure 1. A. Kana Keoki cruise KK810626 Leg 4 ship track (fine line) with magnetic lineations that surround the Mariana Basin. B. Sketch map of the western Pacific showing Kana Keoki ship track (thin solid line), M-25 magnetic anomalies (Cande et al., 1978) (thick solid line), and selected DSDP sites (dots with site number). Site surveys shown as numbered boxes: (1) Seamount 853, (2) MZP-6, (3) MZP-3, (4) Sylvania Guyot. Figure after Shipley et al. (1983).

changed, except that the Jurassic anomalies have been extended back to M29 (Cande et al., 1978). The Japanese lineations are also identified to M29, and Hussong and Fryer (1982) mapped northeast-trending Anomalies M23 to M25 northeast of Guam. With this information on magnetic anomalies in the western Pacific came many more interpretations of the tectonic evolution of the $\mathrm{Pa}$ cific Plate, but still no more conclusions about the Mariana Basin, other than that it should be Jurassic Pacific crust. We refer the reader to the following papers (in chronological order) for Pacific evolutionary models: Hayes and Pitman, 1970; Larson and Pitman, 1972; Larson and Chase, 1972; Moberly and Larson, 1975; Lancelot and Larson, 1975; Winterer, 1976; Larson, 1976; Jackson and Schlanger, 1976; Hilde, et al., 1977; Tamaki et al., 1979; Orwig and Kroenke, 1980; Schlanger and Premoli Silva, 1981.

Before DSDP Leg 89, three DSDP holes in the Mariana Basin were drilled in hope of sampling Jurassic crust: Sites 59 and 61 southeast of Guam and Site 199 east of Guam at $156^{\circ} \mathrm{E}$ longitude. Drilling at Site 59 recovered Eocene and Paleocene clay and bottomed out at $1135 \mathrm{~m}$ in Cretaceous cherty and ashy clay (Heezen, Fischer, et al., 1971). Coring at Site 61 sampled clays and Upper Cretaceous cristobalitic mudstones associated with tuff, and ended in amygdaloidal basalt at $96 \mathrm{~m}$ (Winterer, Riedel, et al., 1971). At Site 199, $456.5 \mathrm{~m}$ of EoceneMiocene turbidites, Upper Cretaceous-Paleocene limestones, and lower Campanian tuff were recovered (Heezen, MacGregor, et al., 1973). Drilling at all three holes failed to reach basement.

In 1978, the Glomar Challenger visited the Nauru Basin southeast of the Mariana Basin. Drilling at Site 462 (Larson, Schlanger, et al., 1981) revealed a thick sequence of Cretaceous intrusive and extrusive basalts under Ter- tiary sediments. The cause of the volcanism is open to speculation, but interpretation of the volcanic complex and correlations with other structures in the Pacific lead to the conclusion that the Cretaceous volcanic event was widespread, possibly worldwide (Larson, Schlanger, et al., 1981; Schlanger and Premoli Silva, 1981). The chances are good that at least parts of the Mariana Basin were affected by the Cretaceous volcanism and may have sill complexes beneath upper Mesozoic as well as Tertiary sediments.

\section{SITE OBJECTIVES AND GEOLOGY}

\section{Seamount 853}

The first site survey conducted aboard the Kana Keoki on cruise KK810626 Leg 4 was "Seamount 853" (the name originates from its depth of 853 fathoms on SIO Bathymetry Map 2203N; Scripps Institute of Oceanography, 1968), located approximately $365 \mathrm{~km}$ east-southeast of Guam (Fig. 1). We approached the site from the west, passing over DSDP Site 61 before entering the area. The survey lasted about 32 hours: one airgun-sonobuoy precision echo recording (ASPER) record was taken, a dredge haul was recovered, and single-channel seismic reflection data were taken continuously on four graphic recorders (low-frequency, $25-50 \mathrm{~Hz}$; mid-frequency, $65-130 \mathrm{~Hz}$; high-frequency $130-260 \mathrm{~Hz}$; and mixedfrequency, $25-50 / 130-260 \mathrm{~Hz}$ ) and on the SIO digital system (the source was one 80 -in ${ }^{3}$ water gun). Gravity and magnetic data were continuously recorded while the vessel was underway. Geophysical data profiled along the ship's track are shown in Figure 2.

Data from 11 cruises (including this survey) were used to produce the bathymetric contour map for Seamount 853 and other seamounts nearby (Fig. 3). Seamount 853 


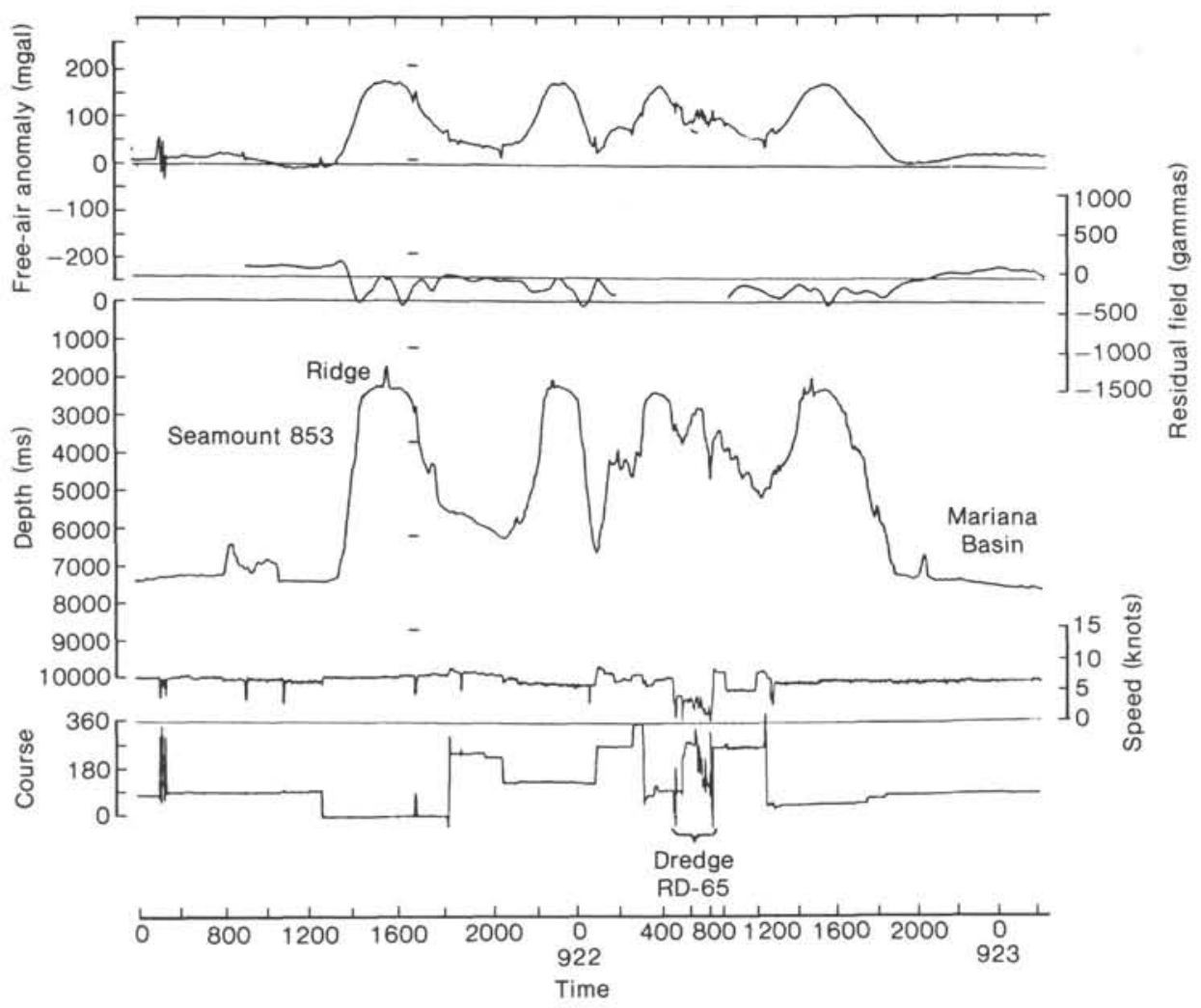

Figure 2. Underway geophysical data profiled along track of Kana Keoki cruise KK810626 Leg 4 over Seamount 853.

(at the center of Fig. 3) rises $3800 \mathrm{~m}$ above the seafloor and has a convex surface with a minimum depth of about $1600 \mathrm{~m}$ below sea level. An east-west-trending ridge about $4 \mathrm{~km}$ across and from 150 to $450 \mathrm{~m}$ high crosses the center of the seamount at about $12^{\circ} 25^{\prime} \mathrm{N}$ (Figs. 2, 3, 4). The seismic reflection profile (Fig. 4) along a NW-SE track across Seamount 853 is from the high-frequency $(130-260 \mathrm{~Hz})$ recorder. The pelagic ooze layer at the center of the seamount is $200 \mathrm{~ms}$ thick and overlies the reef cap at $2.4 \mathrm{~s}$. Fringing reef is visible at the right. The ridge was crossed at the western edge, and is only $150 \mathrm{~m}$ high in this profile. The ridge may be an erosional remnant of a subaerial volcano that existed when the seamount was above sea level. Dredge RD-65 on the southeast slope of Seamount 853 was successful in recovering samples of basalt, andesite(?), limestone, beachrock, and chert with manganese crusts. One sample was determined to be Cretaceous (C. Mato, personal communication, 1981).

The free-air gravity map (Fig. 5) was constructed using data from a total of six cruises. There is a maximum of about +170 mgal over Seamount 853 , and in general the gravity contours follow the bathymetric contours. This positive gravity anomaly indicates that the seamount is not compensated (at least not locally).

Eleven cruises (including ours) passed over this site collecting residual-magnetism data. After correction for diurnal variations and reduction of the data to one International Geomagnetic Reference Field (IGRF) level (1979) (International Association of Geophysics and Aeronomy, 1976), only four cruises (DSDP61, ERDC09,
KK81062604, V1907) had usable data, so we have only a fair amount of confidence in the magnetic contour map (Fig. 6). There appears to be a maximum of about 0 gammas over the center of Seamount 853, and a low of - 300 gammas on the north side, and another low of about -400 gammas on the southeast flank of the seamount. No attempt has been made to model the magnetic signature.

Before reaching the Seamount 853 region, our ship passed over DSDP Site 61 , located about $100 \mathrm{~km}$ southwest of Seamount 853 (Fig. 1). Drilling recovery at this site includes Tertiary clays and Upper Cretaceous cristobalitic mudstones with tuff (Winterer, Riedel, et al., 1971). The hole bottomed out in basalt at $96 \mathrm{~m}$; this basalt may be related to that of the nearby seamounts (Kroenke and Moberly, 1971).

On the basis of its age, depth below sea level, and thick reef cap, we suspect that Seamount 853 may have been formed by the Cretaceous volcanism, or at least affected by the associated uplift. Drilling of Seamount 853 could reveal subsidence history, and may show that Cretaceous volcanism extended as far west as the present-day Mariana Trench.

\section{MZP-6 (DSDP Site 585)}

Our MZP-6 survey in the eastern part of the Mariana Basin includes DSDP Site 199 , located at $13^{\circ} 30.8^{\prime} \mathrm{N}$, $156^{\circ} 10.3^{\prime} \mathrm{E}$ (Fig. 1). The Glomar Challenger visited this spot in 1971 (Heezen, MacGregor, et al., 1973) and drilled $456.5 \mathrm{~m}$ of Tertiary and Upper Cretaceous sediments (basement was not reached). Seismic reflection records 


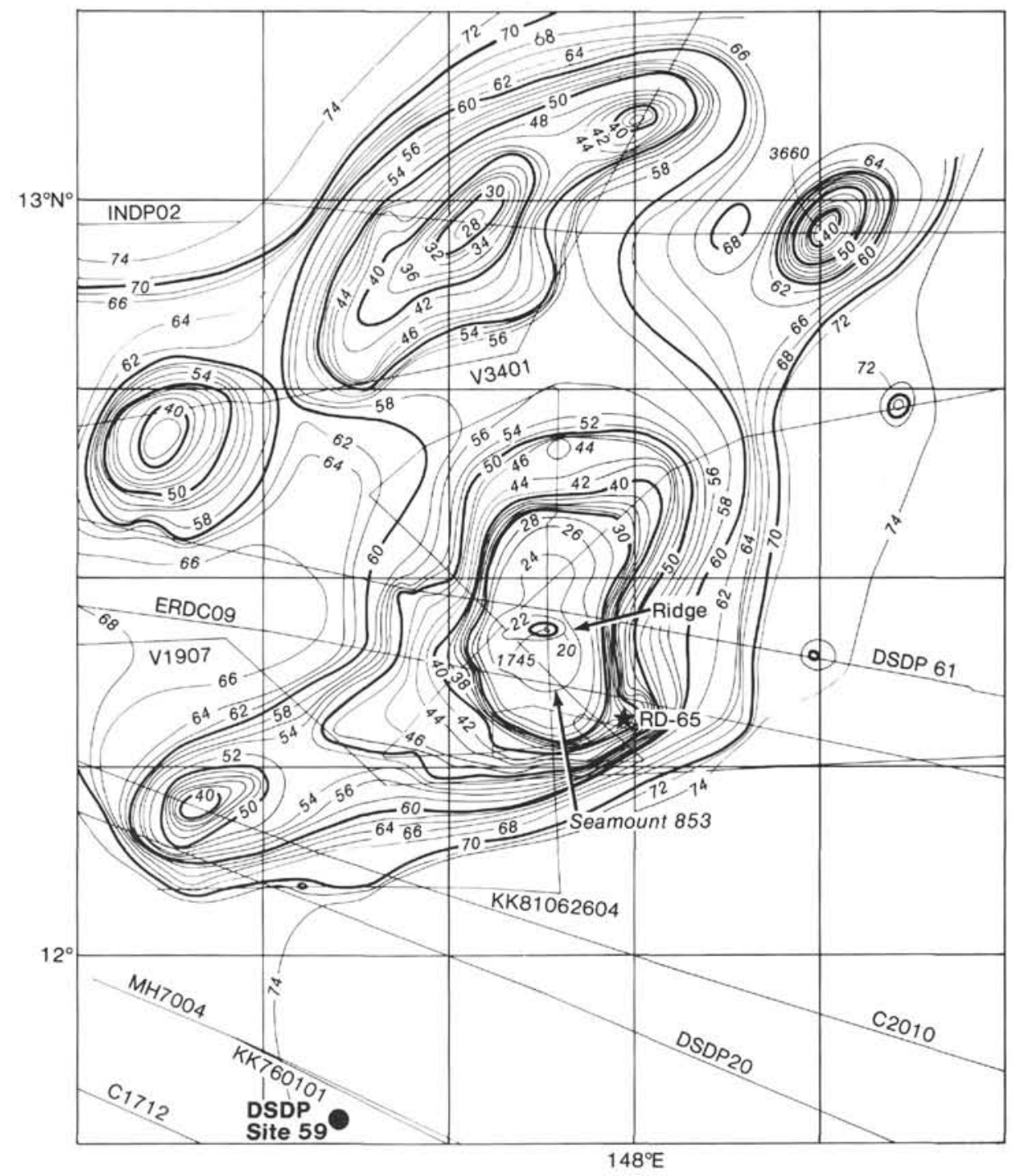

Figure 3. Bathymetry of Seamount 853 (at center) and neighboring seamounts. Multiply values by 100 to get depth in ms; contour interval $200 \mathrm{~ms}$. Ship tracks are shown with fine lines and identified by abbreviated cruise names and numbers. Star shows location of dredge RD-65 on side of Seamount 853.

obtained by the Challenger were poor. Our objective during this site survey was to produce good reflection records and to "see" through sediments and suspected sills to basement.

The Kana Keoki entered the area from the west, surveyed Site 199 in a bow-tie pattern (crossing the site three times), and departed to the east (Fig. 1). Gravity and magnetic readings were taken continuously, as were seismic reflection data on the four graphic recorders and the SIO digital system (two 80 -in ${ }^{3}$ water guns were used as the source), and an ASPER record was made each time the ship passed over Site 199. Underway geophysical data are profiled along the ship's track in Figure 7. No coring or dredging was attempted.

The bathymetry map of the MZP-6 area was constructed with data from a total of six cruises (Fig. 8). Across the center of the survey area is a flat-floored basin, about $6100 \mathrm{~m}$ below sea level, which rarely shows more than
$30 \mathrm{~m}$ of relief. One pinnacle $1050 \mathrm{~m}$ high is located about $15 \mathrm{~km}$ southwest of Site 199. A cluster of seamounts rising about $4600 \mathrm{~m}$ above the seafloor (to 1500 $\mathrm{m}$ below sea level) to the north of the flat basin is shown on the SIO Bathymetry Map $2103 \mathrm{~N}$ in slightly different form (Scripps Institution of Oceanography, 1968). Ita Maitai Guyot (drilled on DSDP Leg 20) also rises 4600 $\mathrm{m}$ above the seafloor, and is shown in the lower righthand area of Figure 8. Ita Maitai is believed to have been affected by the uplift associated with the Cretaceous volcanism (Schlanger and Premoli Silva, 1981); the other seamounts in this region may also have been affected.

A sediment isopach map (Fig. 9) was produced primarily from KK810626 Leg 4 reflection records; KK810626 Leg 2 airgun records, taken north of Ita Maitai Guyot, were also used. In general, there are no sediments on the seamount slopes, and the thickest sediment section occurs 


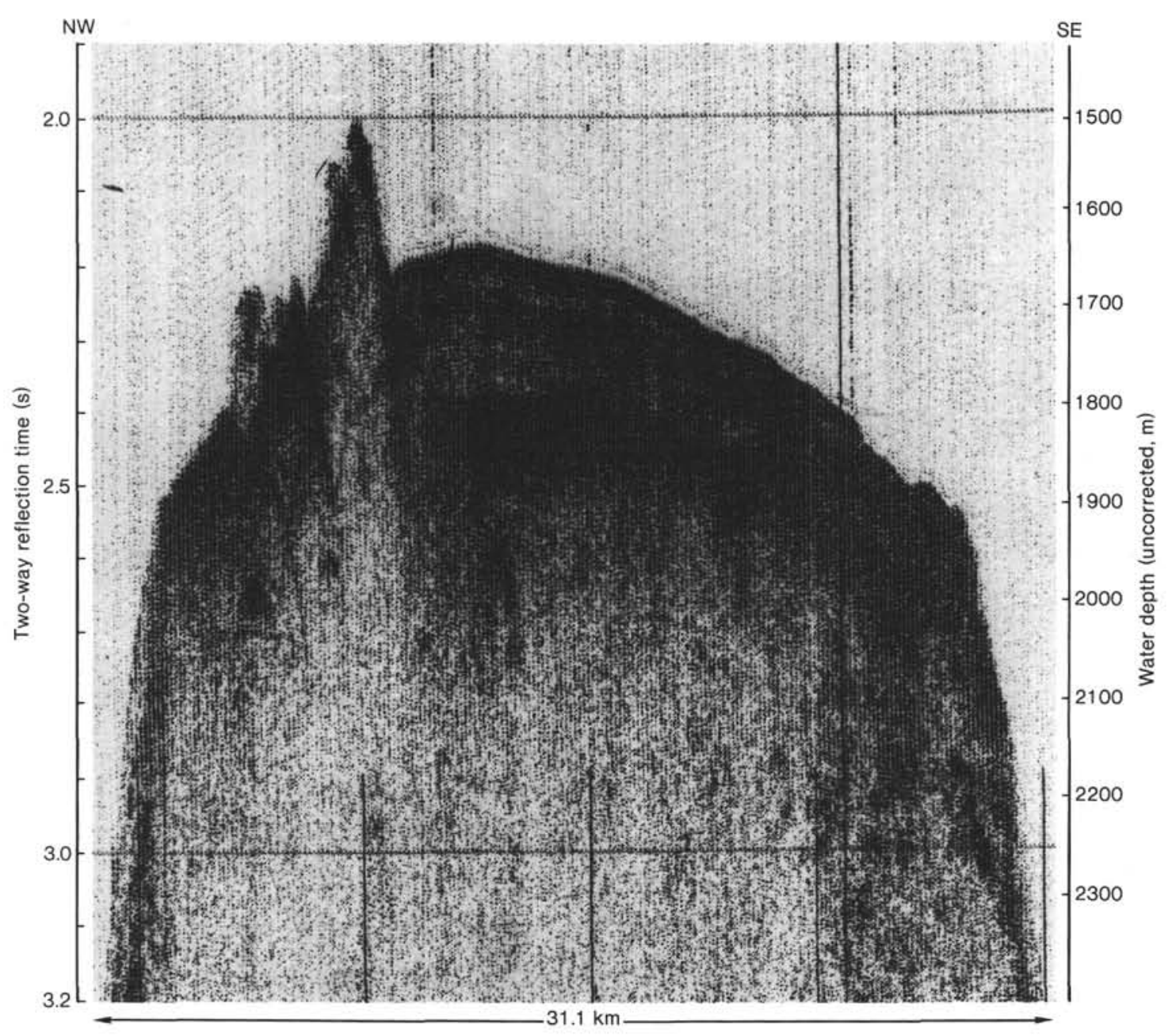

Figure 4. Seismic reflection profile along a NW-SE track across Seamount 853 , from the high-frequency $(130-260 \mathrm{~Hz}) \mathrm{re}-$ corder. The pelagic ooze layer at the center of the seamount is about $200 \mathrm{~ms}$ thick. The reflector at $2.4 \mathrm{~s}$ is probably the reef cap. Fringing reef is at right. Dredge RD-65 was taken from the southeast slope of Seamount 853 near the right edge of this profile.

in the basin. This contour map indicates that the pinnacle southwest of Site 199 could be a linear ridge instead of an isolated seamount. Reflection records from our track along $13^{\circ} 30^{\prime} \mathrm{N}$ latitude east of Site 199 show the sediments to be about 1100 ms thick near the center of the basin. Figure 10 shows the digitally processed form of seismic reflection data recorded by SIO, together with lithologic interpretation of the reflectors by Shipley et al. (1983). These investigators determined that the upper $640 \mathrm{~ms}$ of section has a velocity of $1830 \mathrm{~m} / \mathrm{s}$, representing $590 \mathrm{~m}$ of turbidites and pelagic deposits below the CCD (carbonate compensation depth). Below this was $260 \mathrm{~m}$ of sediments with a velocity of $2010 \mathrm{~m} / \mathrm{s}$. The interval from 9.0 to $9.1 \mathrm{~s}$ was believed to be $150 \mathrm{~m}$ of limestones with a velocity of $3000 \mathrm{~m} / \mathrm{s}$, deposited above the CCD. Basaltic basement, then, appeared to be about $7100 \mathrm{~m}$ below sea level.

A free-air gravity map was compiled with data from five cruises, including KK810626 Leg 4 (Fig. 11). Positive anomalies are located at the seamounts. There is a negative anomaly of $-60 \mathrm{mgal}$ over the thick sediments east of Site 199.
Residual magnetism values collected in the MZP-6 area were too sparse to allow contouring or interpretation.

We recommended to Leg 89 scientists that the basin east of Site 199 would be the best location for drilling to Jurassic(?) Pacific crust. The 1000 -m-thick sediment section appeared to lack any sills or flows, and oceanic basement appeared to lie at about $7100 \mathrm{~m}$. Although the surrounding seamounts may be Cretaceous, we believed that the basin might have been affected to some extent by uplift, but did not contain Cretaceous sills or flows. Drilling at Site 585 by the Glomar Challenger on Leg 89 ended in upper Aptian to middle Albian sediments at a depth of $893 \mathrm{~m}$. Basement of unknown age possibly lies deeper than our site survey data predicted.

\section{MZP-3}

The third site survey was in a small basin east of the Mariana Basin between $159^{\circ} \mathrm{E}$ and $160^{\circ} \mathrm{E}, 13^{\circ} 30^{\prime} \mathrm{N}$ and $14^{\circ} 30^{\prime} \mathrm{N}$ (Fig. 1). After the MZP-6 survey, we spent about 10 days in the MZP-3 area before leaving for Sylvania Guyot. Four cores, one dredge (unsuccessful recovery except for some mid-Eocene mud; C. Mato, personal 


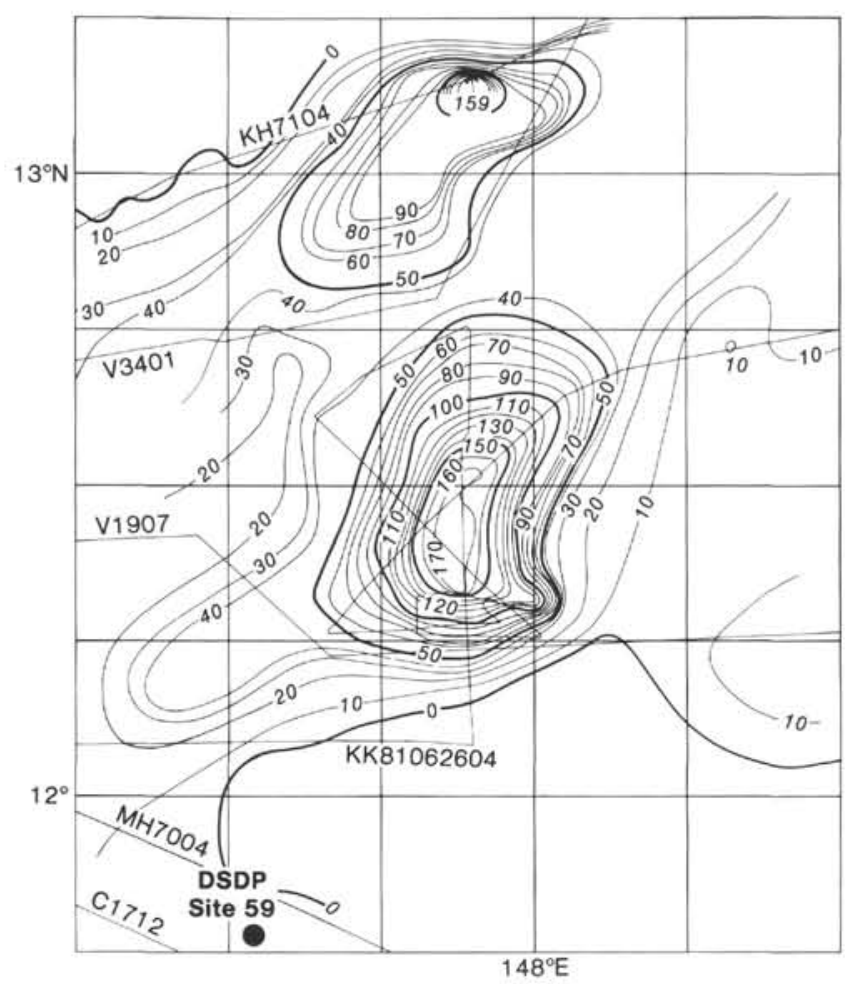

Figure 5. Free-air gravity contour map of Seamount 853 . Values in mgal; contour interval $10 \mathrm{mgal}$. Ship tracks are shown with fine lines and identified by abbreviated cruise names and numbers.

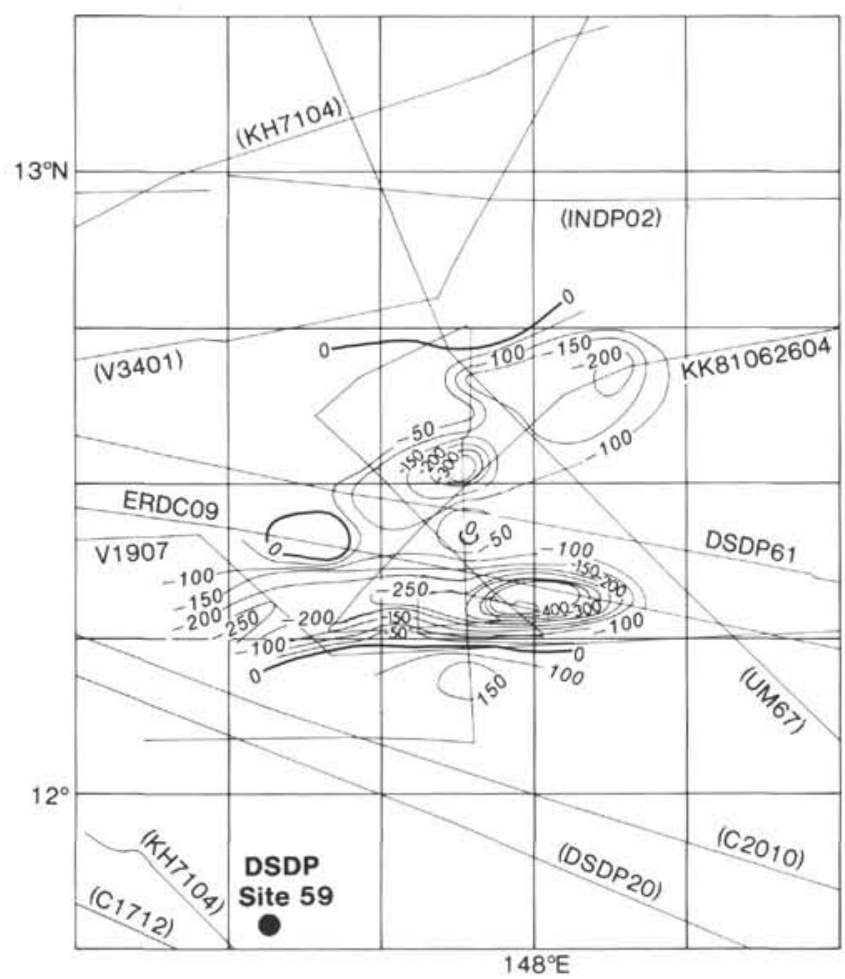

Figure 6. Residual magnetic contour map of Seamount 853. Values in gammas; contour interval 50 gammas. Ship tracks are shown with fine lines and identified by abbreviated cruise names and numbers. Cruises for which data were not usable are identified by parentheses. communication, 1982), and nine ASPERs were taken during this survey. Seismic reflection data were taken continuously on the aforementioned recorders, and gravity and magnetic readings were also taken continuously. The sources used here were one or two 80 -in ${ }^{3}$ water guns, and occasionally one water gun and one 120 -in ${ }^{3}$ airgun. Underway geophysical data are profiled along the ship's track in Figure 12.

A bathymetric contour map (Fig. 13) of the MZP-3 area was made using data from six cruises and SIO Bathymetry Maps $2103 \mathrm{~N}$ and 2002N (Scripps Institute of Oceanography, 1968). The seafloor at this site is shallower than in the MZP- 6 region, averaging about $5600 \mathrm{~m}$ below sea level. The concentrated area of survey in the center of Figure 13 is surrounded by several isolated seamounts: one in the west, one in the north, two in the northeast, and probably one in the southwest. Prominent in the MZP-3 area are several WNW-trending ridges about $8 \mathrm{~km}$ across, varying in relief up to $800 \mathrm{~m}$ high. An attempt to dredge one of these ridges failed to recover any rock.

A seismic profile from the low-frequency $(25-50 \mathrm{~Hz})$ recorder along a N-S track (shown in Fig. 13) is provided in Figure 14. Stratigraphy and sediment thickness in the troughs between ridges in this profile vary, as is typical throughout the MZP-3 region. Shipley et al. (1983) have described the seismic characteristics of the sediment and presented the following lithologic interpretation: the upper layer consists of reworked pelagic clays, the intermediate layer is composed of pelagic biogenic material and clays derived from the nearby topographic highs, and the lowermost layer above acoustic basement was unidentifiable. No ages are known for any of the layers.

Two sediment isopach maps were made with KK810626 Leg 4 reflection records: transparent layer from $3.5-\mathrm{kHz}$ records, and total sediment thickness (or depth to acoustic basement) from low-frequency $(25-50 \mathrm{~Hz})$ reflection records. The transparent layer, probably turbidite muds, is $60 \mathrm{~ms}$ thick at most (Fig. 15). Generally, on topographic highs, the transparent-layer thickness is 0 , but in some flat, low-lying regions the thickness is also 0 . The sediment isopach map (Fig. 16) shows that the sediment thickness in the MZP-3 area averages about $400 \mathrm{~ms}$. Over topographic highs, sediment thickness is 0 , and in pockets between bathymetric features, thickness can reach up to $900 \mathrm{~ms}$.

Free-air gravity data from five cruises including ours were used to construct the contour map in Figure 17. In general, positive anomalies are found over topographic highs and negative anomalies are found in the flat basin areas.

Residual-magnetism data from six cruises were used to make the magnetic contour map (Fig. 18). After correction for diurnal variations and reduction to the 1979 IGRF level (International Association of Geophysics and Aeronomy, 1976), only three cruises (KK81062604, V3214, C2003) were given serious consideration for contouring. Amplitudes are small, ranging from +60 to -140 gammas. From interpretation of the magnetic data, we are 


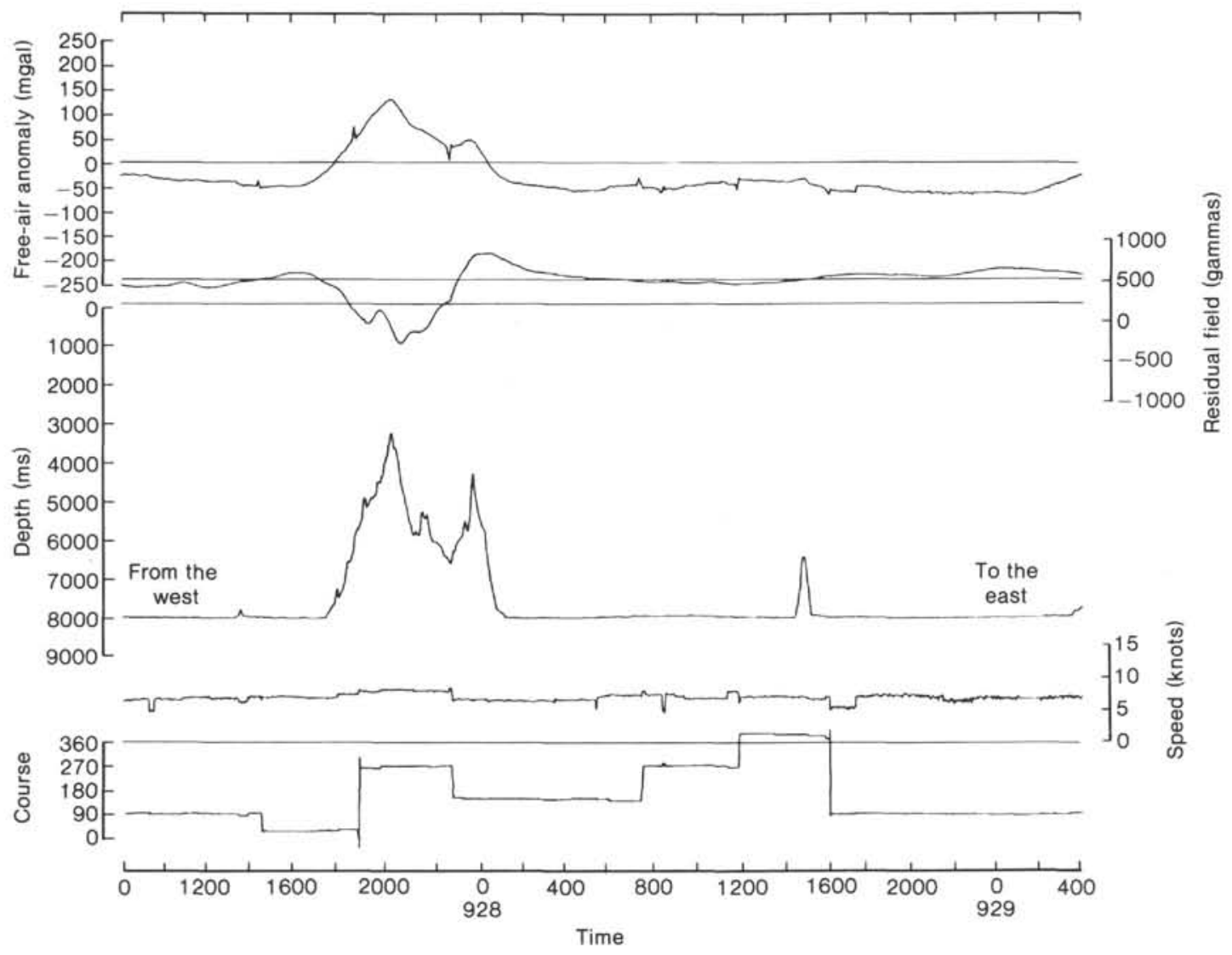

Figure 7. Underway geophysical data profiled along track in the MZP-6 region.

able to conclude only that the MZP-3 region was probably formed during a magnetic quiet period.

Four piston cores were taken in the MZP-3 region (see Fig. 13 for core locations, Table 1 for physical properties, and Appendix B for lithologic sections of these cores.) Core PCOD-04 was located at $13^{\circ} 49^{\prime} \mathrm{N}, 159^{\circ} 26^{\prime} \mathrm{E}$, at a corrected water depth of $5516 \mathrm{~m}$ near the center of a small basin between the WNW-trending ridges common in this area. The $3.5-\mathrm{kHz}$ records show about $15 \mathrm{~m}$ of transparent sediments at the top of the sediment column. Total core length recovered was $1227 \mathrm{~cm}$. Sediment is dark brown to dark yellowish brown zeolite-rich clay. Mottling is sparse and scattered throughout the core. Traces of radiolarians, foraminifers, and fish teeth were found during smear-slide analysis.

Piston Core PC-05 was taken at $14^{\circ} 21^{\prime} \mathrm{N}, 159^{\circ} 42^{\prime} \mathrm{E}$, at a corrected water depth of $5585 \mathrm{~m}$ in an area where very little of the transparent layer was visible on the $3.5-\mathrm{kHz}$ records (Figs. 13, 15). Core length recovered was $313 \mathrm{~cm}$. The top $35 \mathrm{~cm}$ of this core is very dark brown zeolite-rich clay. The remainder of the core is very dark grayish brown to dark yellowish brown zeolitic clay. Thin sandy layers (less than $8 \mathrm{~cm}$ ) are located at 0.85 , 209 , and $279 \mathrm{~cm}$. Mottling is very slight to heavy throughout the core. Rock fragments include manganese nodules (top of core), chert(?) $(305 \mathrm{~cm})$, and small chips of undetermined composition (bottom of core). Age at the bottom of the core is probably Paleocene (C. Mato, personal communication, 1982). The core cutter contained indurated clays with Cretaceous radiolarians. The boundary between the brown clay and the indurated material probably marks the base of the transparent layer in this part of the survey area.

The third core, PC-06, was located at $14^{\circ} 11^{\prime} \mathrm{N}, 159^{\circ}$ $21^{\prime} \mathrm{E}$, at a corrected water depth of $5582 \mathrm{~m}$ (Fig. 13), where the $3.5-\mathrm{kHz}$ reflection records showed the transparent layer to be about 2 to $5 \mathrm{~m}$ thick. We had hoped to sample the sediments below the transparent layer, but we are not certain that any of the core properties correlate with the change seen on the reflection record. The total core length recovered was $973 \mathrm{~cm}$. The sediment from 0 to $637 \mathrm{~cm}$ is dark reddish brown clay containing trace amounts of fish teeth. Sediment from 637 to $710 \mathrm{~cm}$ is dark brown clay, and from 710 to $825 \mathrm{~cm}$ it consists of dark brown clay containing traces of fish teeth. Sediment from 825 to $925 \mathrm{~cm}$ is dark brown clay. From $925 \mathrm{~cm}$ to the bottom of the core, sediment is dark brown to dark yellowish brown zeolite-rich clay. A sample of Core PC-06 between 962 and $970 \mathrm{~cm}$ was analyzed at SIO for age determination. The presence of ichthyoliths indicated that the sediments are upper Paleocene through middle Eocene (P. Doyle, personal communication, 1982). Mottling is very slight to heavy throughout the core. Rock fragments were found at the top of the core and at 590, 644, and $699 \mathrm{~cm}$.

The last piston core (PC-07) at this site survey was located at $14^{\circ} 05^{\prime} \mathrm{N}, 159^{\circ} 27^{\prime} \mathrm{E}$, at a corrected water depth of $4810 \mathrm{~m}$ (Fig. 10). Since the dredge recovery was un- 


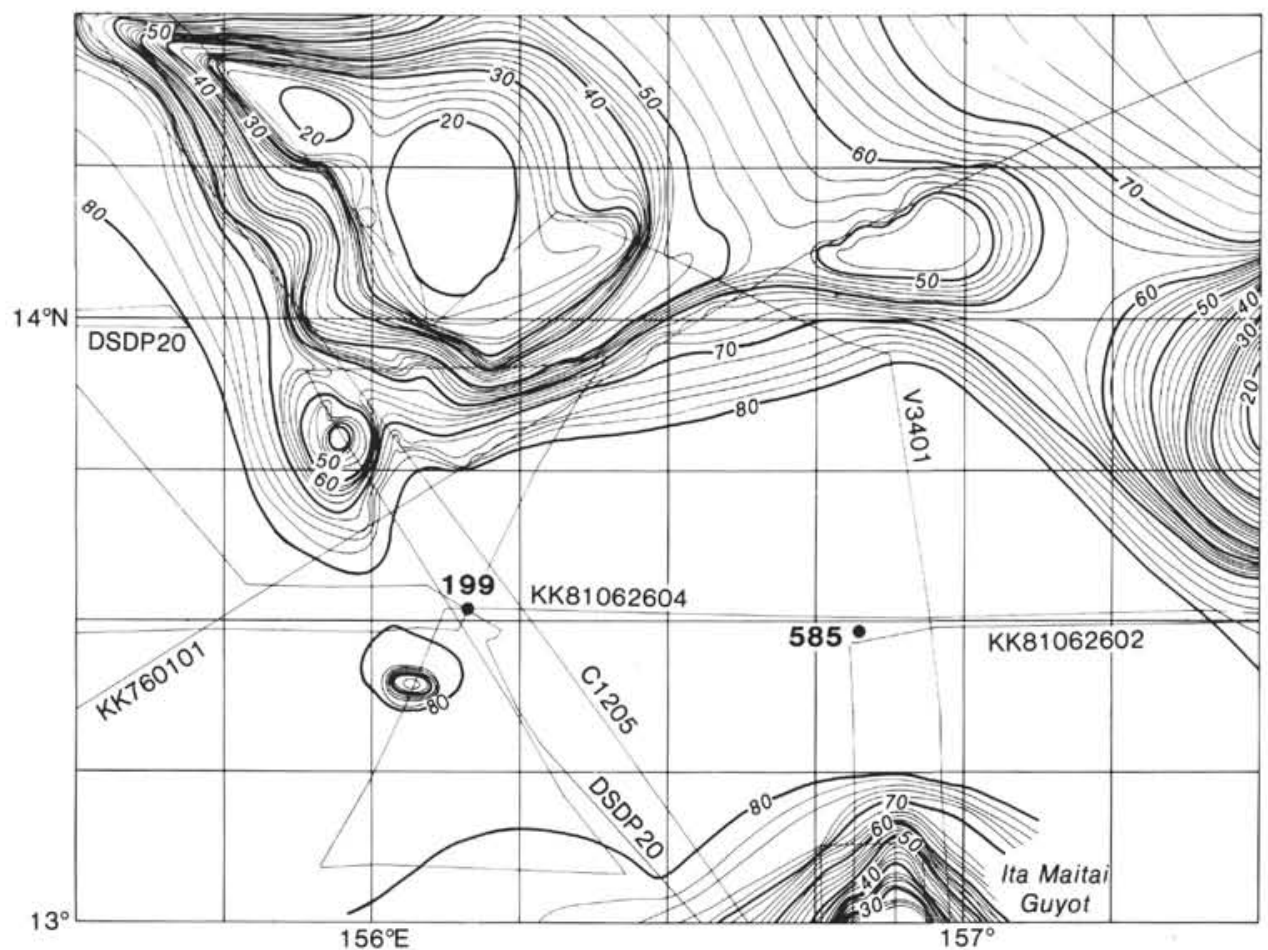

Figure 8. Bathymetry of the MZP-6 area. Multiply values by 100 to get depth in ms; contour interval 200 ms. Ship tracks (shown with fine lines and identified by abbreviated cruise names and numbers) and SIO bathymetry maps (Scripps Institution of Oceanography, 1968) comprise data base for this map. DSDP Site 199 is at $13^{\circ} 30.8^{\prime} \mathrm{N}, 156^{\circ} 10.3^{\prime} \mathrm{E}$. DSDP Site 585 is at $13^{\circ} 29.0^{\prime} \mathrm{N}, 156^{\circ} 48.91^{\prime} \mathrm{E}$. DSDP sites are shown as dots with site numbers. The north slope of Ita Maitai Guyot is at bottom right. Area of Figure 13 is to the right.

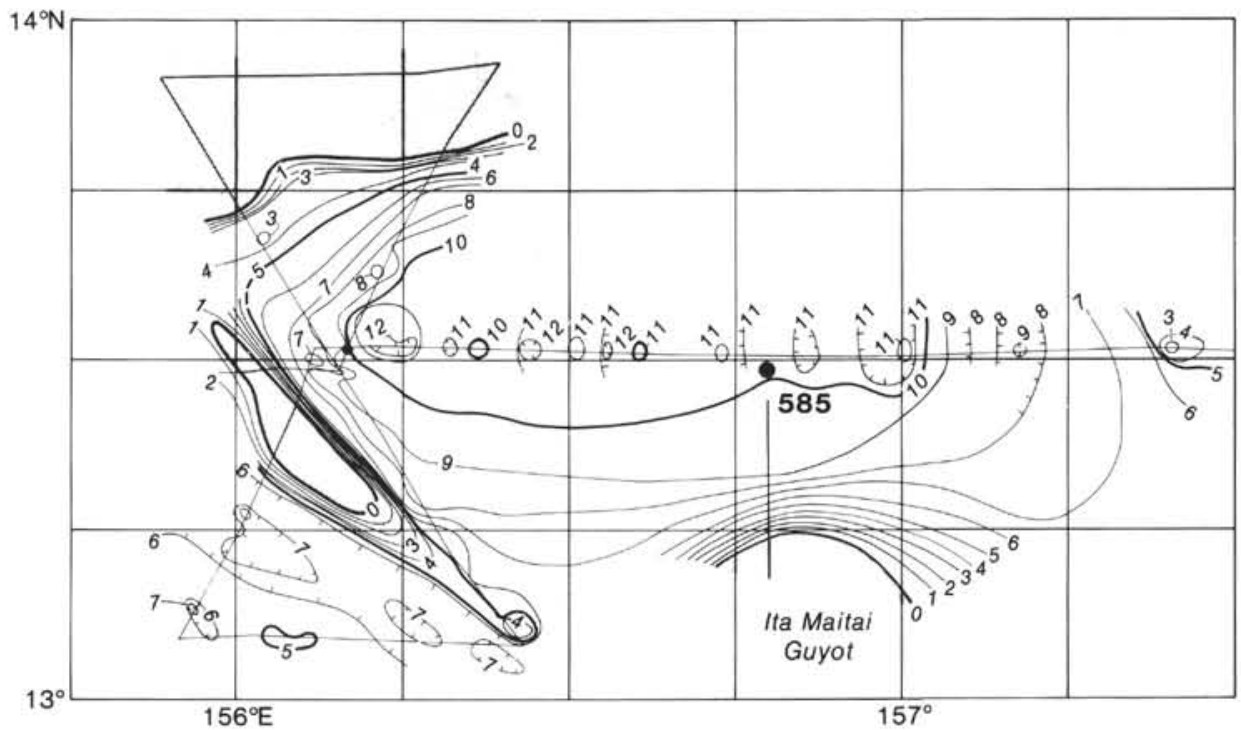

Figure 9. Total sediment thickness in the MZP-6 area, determined from low-frequency reflection records collected by cruises KK810626 Leg 2 and KK810626 Leg 4. Multiply values by 100 to get thickness in $\mathrm{ms}$; contour interval $100 \mathrm{~ms}$. Ship tracks are shown by fine lines. DSDP sites are shown as dots with site numbers.

successful, this core was taken in an attempt to determine the nature of the WNW-trending ridges. Total core length is $736 \mathrm{~cm}$. Sediment from 0 to $575 \mathrm{~cm}$ is dark yellowish brown clay. The lower portion of the core, from 575 to $736 \mathrm{~cm}$, is dark yellowish brown clay. Mottling is very slight in the upper portion of the core. Rock fragments were found at $4 \mathrm{~cm}$ (manganese nodule), 718 to $736 \mathrm{~cm}, 723 \mathrm{~cm}$, and $730 \mathrm{~cm}$. The rock fragments at the bottom of the core correlate with acoustic basement on the $3.5-\mathrm{kHz}$ reflection records, and therefore may be 


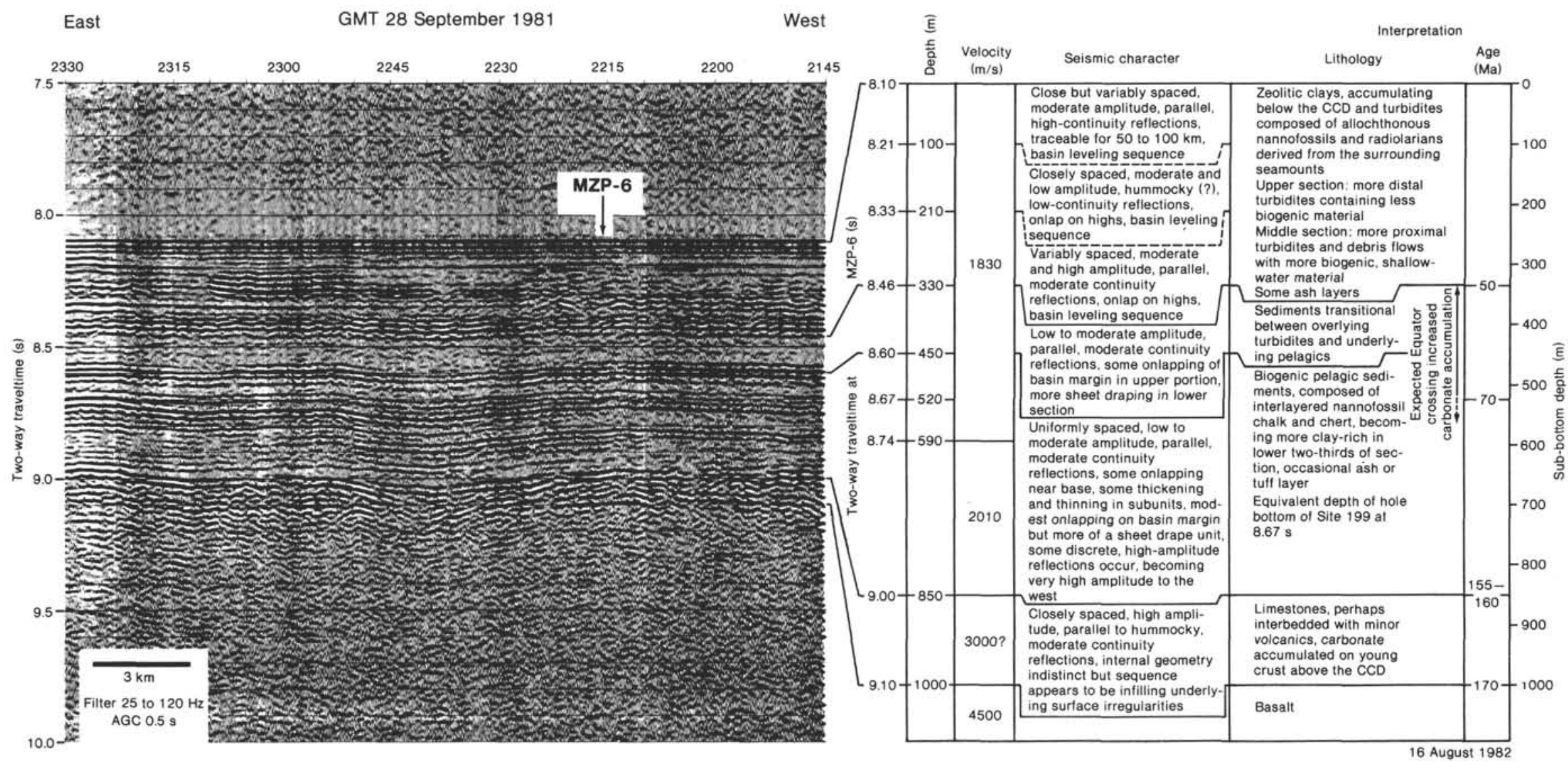

Figure 10. Seismic reflection section with lithologic interpretation of the basin east of Site 199. Location of recommended drill site for DSDP Leg 89 is labeled "MZP-6," and the actual location of Site 585 is about $5 \mathrm{~km}$ to the south. Figure is taken from Shipley et al. (1983). 


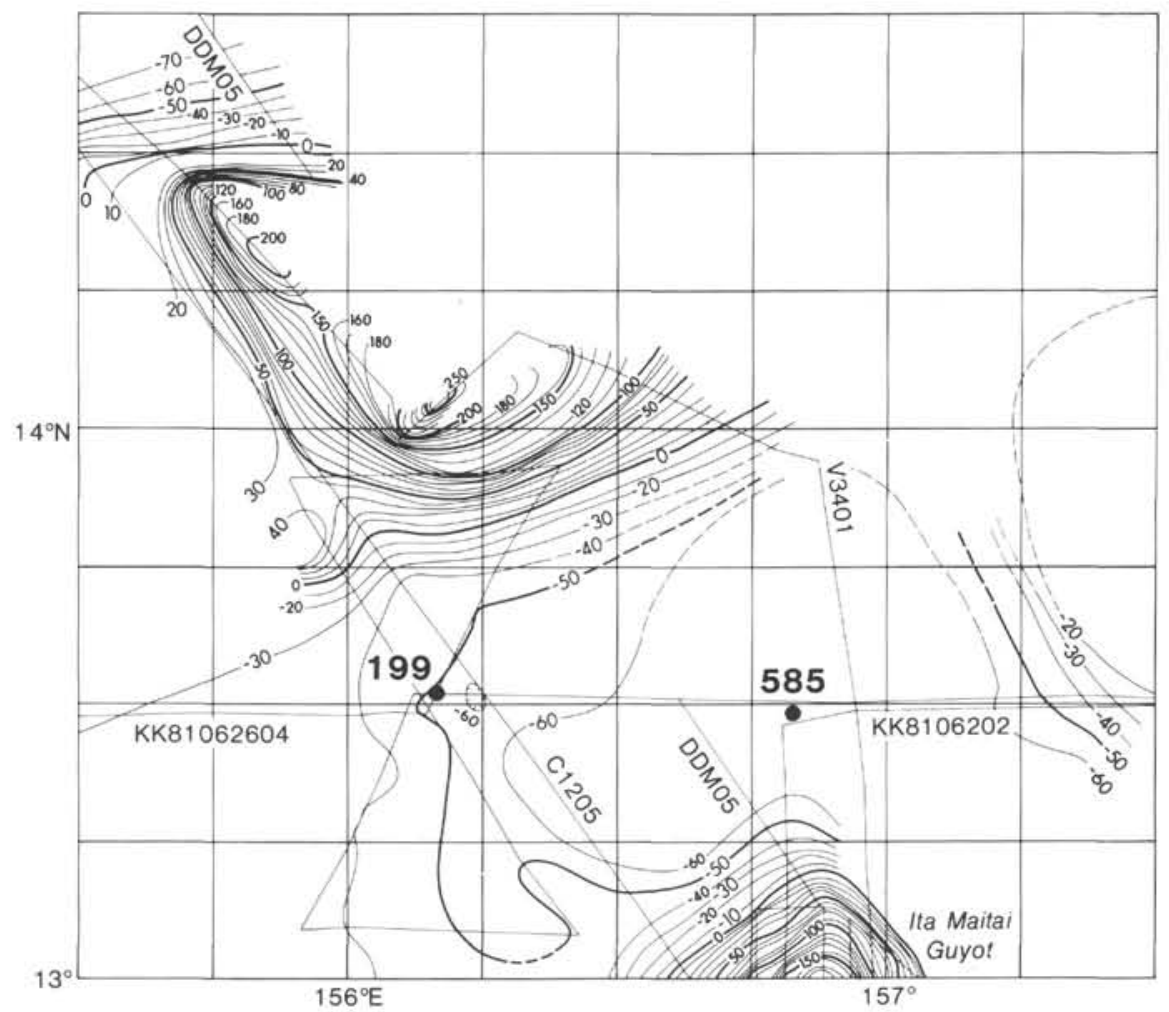

Figure 11. Free-air gravity contour map of the MZP-6 area. Values in mgal; contour interval $10 \mathrm{mgal}$. Ship tracks are shown as fine lines and identified by abbreviated cruise names and numbers. DSDP sites are shown as dots with site numbers.

samples of the ridges themselves. The fragments are severely altered, but appear to be basaltic; one sample could be a pillow fragment (J. Sinton, personal communication, 1982).

Owing to the complex topography, thin sediment cover, and relatively shallow basement depth of the MZP-3 region, we concluded that this would be a poor site for drilling to Jurassic(?) crust. Our survey suggested, however, two interesting questions pertinent to the eastern part of the Mariana Basin: What is the nature and origin of the WNW-trending ridges, and how can the differences in depth to basement and sediment thickness between the MZP- 6 and MZP-3 regions be explained?

Unfortunately, we feel that our data base is too limited to provide answers to these questions with any certainty. Only a few ships have passed through this area, and only the Kana Keoki stopped to do any detailed surveying. Drilling results at Sites 199 and 585 give insight into the sedimentation history of the MZP- 6 region, but apparently cannot be applied to the MZP-3 area. Further, no ages are available for oceanic basement in the Mariana Basin, and magnetic anomalies have not been identified with confidence.

We can, however, speculate on possible solutions to these problems. The WNW-trending ridges, on the basis of their orientation, could be (1) abyssal hills related to the Hawaiian magnetic lineations, or (2) fracture zones related to either the Japanese or the Phoenix magnetic lineations, or (3) remnants of a short-lived spreading center not unlike the Early Cretaceous spreading center in the central Pacific basin. Shipley et al. (1983) prefer to interpret the ridges and troughs as fracture zones instead of abyssal hills because of the rather high relief of the basement (up to about $1000 \mathrm{~m}$ ) and the varying stratigraphy. In their relief, orientation, and somewhat fanshaped character, the ridges resemble the Early Cretaceous spreading center described by Tamaki et al. (1979), but there are apparently no magnetic anomalies to substantiate this.

The depth to basement varies considerably between MZP-6 and MZP-3. In the MZP-6 region, average water depth is $6100 \mathrm{~m}$ and average sediment thickness is about $1000 \mathrm{~m}$, for an isostatically compensated basement depth of $6600 \mathrm{~m}$ below sea level. In the MZP-3 region, average water depth and sediment thickness are 5600 and $400 \mathrm{~m}$ (assuming average sediment velocity of $2000 \mathrm{~m} / \mathrm{s}$ ), respectively, giving a $5800 \mathrm{~m}$ depth to basement after correcting for sediment load. The 800 -m difference could result from (1) younger MZP-3 crust separated from older MZP-6 crust by a fracture zone, or (2) the MZP-3 region having been uplifted (i.e., reheated), or (3) the acoustic basement at MZP-3 representing Cretaceous sills or flows overlying Jurassic(?) crust, or (4) a younger crust formed by a spreading center in the MZP-3 region. In any case, a tectonic boundary of some kind exists between MZP-6 and MZP-3, and further investigation is necessary to begin to understand the evolution of this part of the Mariana Basin.

\section{Sylvania Guyot}

Sylvania Guyot is adjacent to Bikini Atoll at $164^{\circ} 50^{\prime} \mathrm{E}$, $12^{\circ} 57^{\prime} \mathrm{N}$ (Fig. 1). The Kana Keoki approached the area 


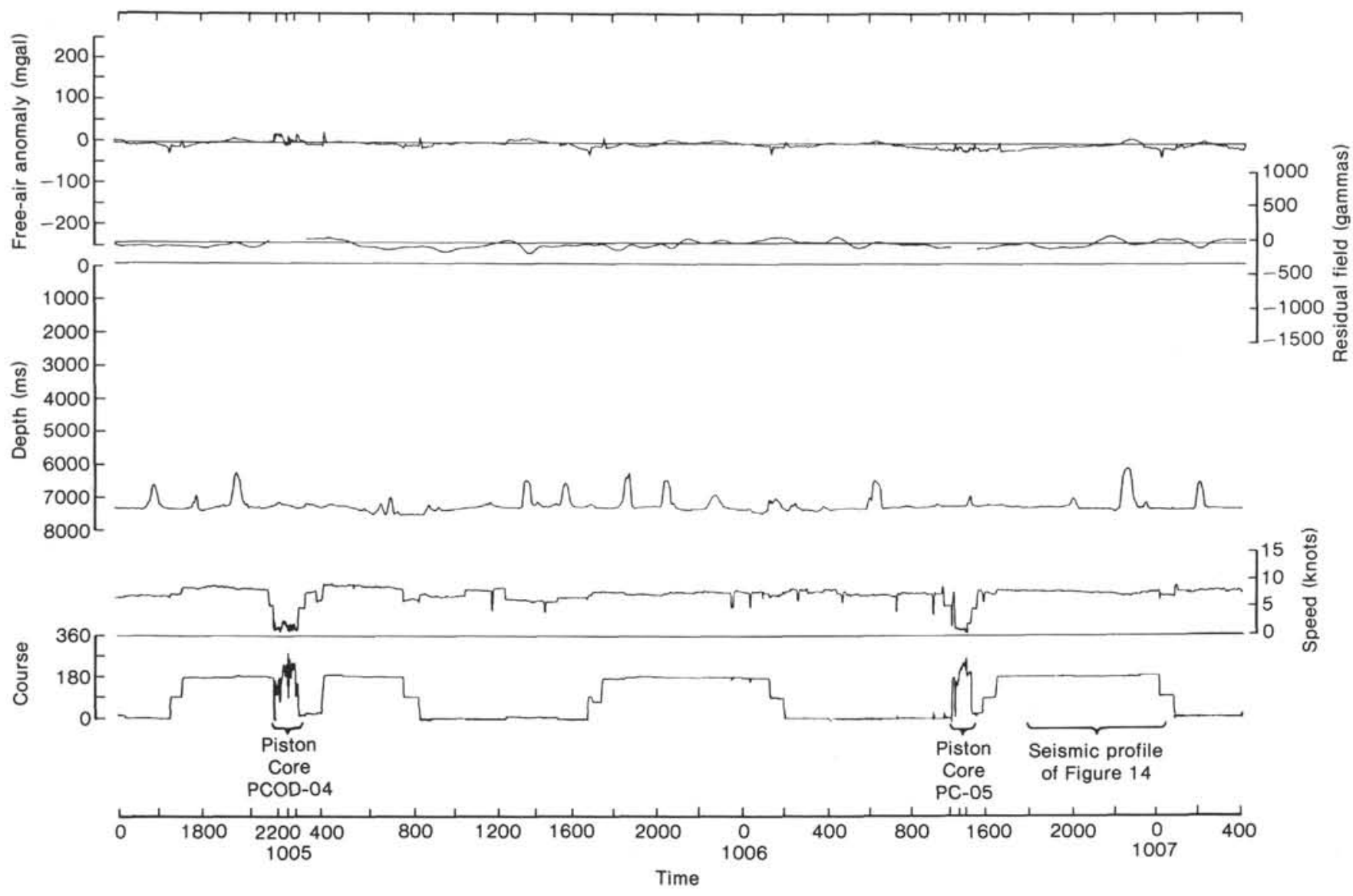

Figure 12. Underway geophysical data profiled along ship's track in the central part of the MZP-3 region.

from the northwest and surveyed for approximately 28 hours. We obtained two ASPER records and recovered a dredge haul, then departed to the north. Seismic reflection records were taken continuously on the four graphic recorders and on the SIO digital system, using an 80 -in ${ }^{3}$ water gun as the source. Gravity and magnetic readings were also continuously recorded while underway. Figure 19 shows geophysical data profiled along the ship's track.

Bathymetric data collected by the Kana Keoki were used, along with the bathymetric chart for Sylvania Guyot by Emery et al. (1954), to produce the contour map in Figure 20. Sylvania is a flat-topped guyot about $1300 \mathrm{~m}$ below sea level, rising $3900 \mathrm{~m}$ above the surrounding seafloor. A layer of pelagic ooze of $110 \mathrm{~ms}$ maximum thickness overlies a reef cap approximately $190 \mathrm{~ms}$ thick. If we assume velocities of $1500 \mathrm{~m} / \mathrm{s}$ for water, $1700 \mathrm{~m} / \mathrm{s}$ for the pelagic ooze layer, and $2000 \mathrm{~m} / \mathrm{s}$ for the reef cap, then basement lies about $1580 \mathrm{~m}$ below sea level. Dredge RD-67 on the southwest slope of Sylvania Seamount (Fig. 20) was successful in recovering samples of volcanic breccia with manganese crust and phosphatized foraminiferal limestone. An age of Eocene has been determined for the limestone (J. Haggerty, personal communication, 1982). Four prominent projections radiate from the center of the guyot to the north, south, westnorthwest, and northeast. A saddle about $1400 \mathrm{~m}$ below sea level joins Sylvania with Bikini Atoll to the southeast.
A seismic reflection profile along an ENE-WSW traverse across Sylvania, from the low-frequency $(25-50 \mathrm{~Hz})$ recorder, is shown in Figure 21.

Free-air gravity contours follow bathymetric contours fairly well (see Fig. 22). Maximum value is $+180 \mathrm{mgal}$ over the center of Sylvania, and another maximum is observed in the saddle between Sylvania and Bikini. These maxima may be the locations of high-density material (such as an old magma chamber or dike swarm). The gravity anomaly also shows that the guyot is not isostatically compensated, implying that it was formed on crust more than 30 m.y. old.

Magnetic data collected by the Kana Keoki were too sparse to produce a contour map. Most readings were taken during daytime hours, which complicated the matter even more, since diurnal variations are strong.

Seamount-atoll pairs, such as Sylvania Guyot-Bikini Atoll and Harrie Guyot-Mili Atoll, in which one edifice has become an atoll while the other has not, are difficult to explain, especially when the ages are similar. Drilling and reflection records from Bikini (Raitt, 1954) show that the volcanic core of the atoll is at a depth of about $1400 \mathrm{~m}$ (Fig. 23), or nearly the same as Sylvania (about $1580 \mathrm{~m}$ ), implying that they are at least of similar ages. Why, then, did Bikini's reefs continue to grow when Sylvania's did not? Could it be that Bikini was slightly higher than Sylvania when sea level rose, and that Sylvania dropped below the photic zone while Bikini was left above it? Dredge RD-67 recovered Eocene fossils, and 


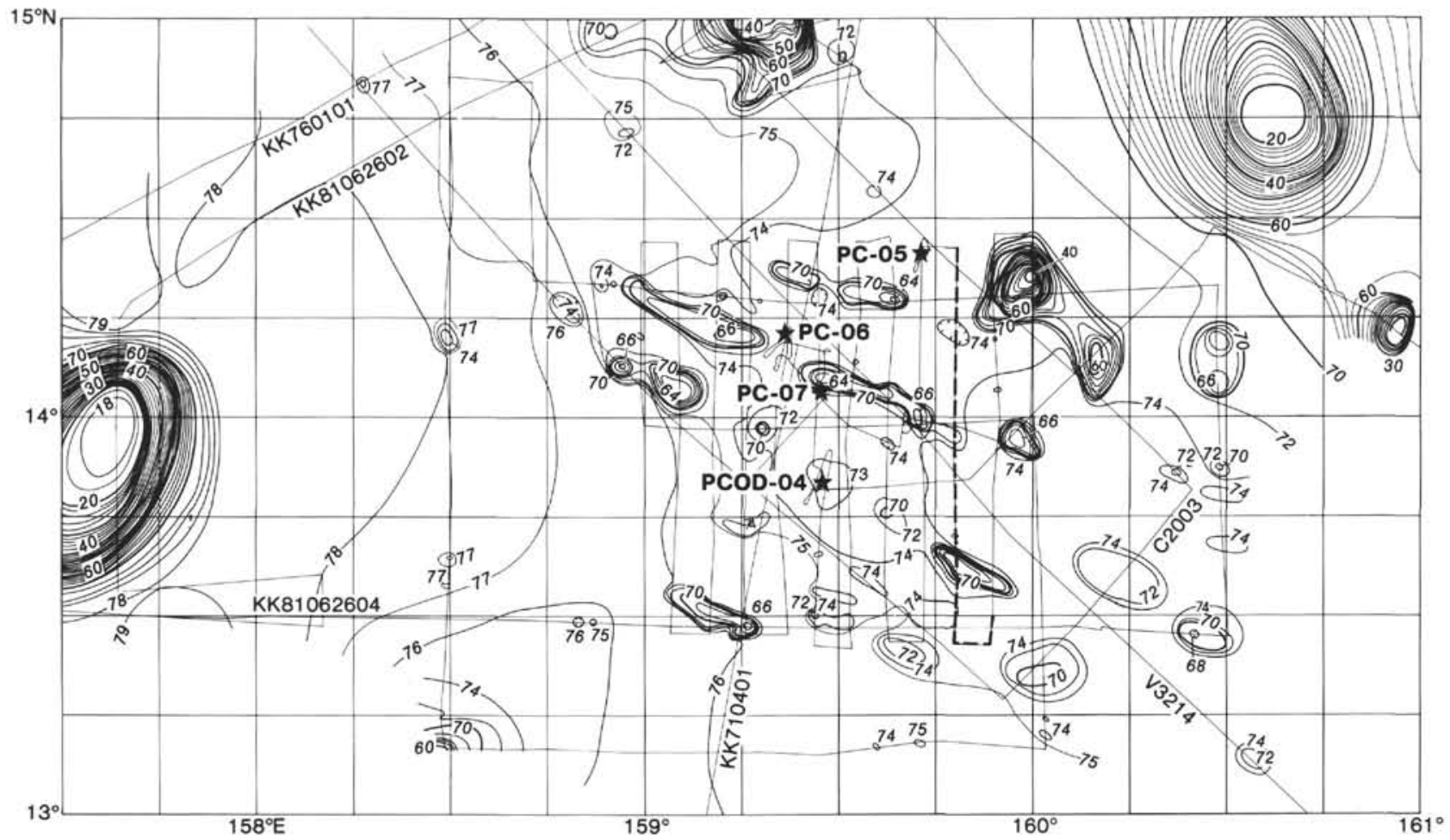

Figure 13. Bathymetry of the MZP-3 site survey. Multiply values by 100 to get depth in ms; contour interval 100 or $200 \mathrm{~ms}$. Ship tracks (shown with fine lines and identified by abbreviated cruise names and numbers) and SIO Bathymetry Maps 2103N and 2003N (Scripps Institution of Oceanography, 1968) were used for contouring. Locations of piston cores are identified by stars with core numbers. Dashed line on ship track shows location of seismic profile of Figure 14. Area of Figure 8 is to the left.

Hamilton and Rex (1957) found Sylvania reef rocks to be Eocene and Miocene. This indicates that the reefs died out during these epochs. Drilling on Sylvania Guyot should provide a simple means of dating the early subsidence history of the area, and possibly could explain why Sylvania is not an atoll.

\section{ACKNOWLEDGMENTS}

This site survey was funded by a contract from Joint Oceanographic Institutions, Inc. We thank the Kana Keoki crew and technicians for their patience and support and the remainder of the science party (Dale Stuber, Elaine Demian, David Cuddy, Chris Mato, Sharon Warlop, Gordon Francis, Terry Francis McArthur, Roger Romei, and Neil Tamashiro) for their dedication and help. We thank Rita Pujalet and Diane Henderson for editorial assistance and Hawaii Institute of Geophysics Graphics for drafting. We thank H. G. Greene and L. Mayer for their review of this paper. Hawaii Institute of Geophysics Contribution No. 1626.

\section{REFERENCES}

Cande, S. C., Larson, R. L., and La Brecque, J. L., 1978. Magnetic lineations in the Pacific Jurassic quiet zone. Earth Planet. Sci. Lett., 41:434-440.

Emery, K. O., Tracey, J. I., Jr., and Ladd, H. S., 1954. Geology of Bikini and nearby atolls. Prof. Pap. U.S. Geol. Surv., 260.

Hamilton, E. L., and Rex, R. W., 1957. Lower Eocene phosphatised Globigerina ooze from Sylvania Guyot, Marshall Islands. Proc. Ninth Pacific Sci. Congr. (Abstract)

Hayes, D. E., and Pitman, W. C., 1970. Magnetic lineations in the North Pacific. In Hays, J. D. (Ed.), Geological Investigations of the North Pacific. Mem. Geol. Soc. Am., 126:291-314.

Heezen, B. C., Fischer, A. G., et al., 1971. Site 59. In Fischer, A. G., Heezen, B. C., et al., Init. Repts. DSDP, 6: Washington (U.S. Govt. Printing Office), 557-586.
Heezen, B. C., MacGregor, I. D., et al., 1973. Mesozoic chalks beneath the Caroline Abyssal Plain, Site 199. In Heezen, B. C., Macgregor, I. D., et al., Init. Repts. DSDP, 20: Washington (U.S. Govt. Printing Office), 65-74.

Hilde, T. W. C., Uyeda, S., and Kroenke, L., 1977. Evolution of the western Pacific and its margin. Tectonophysics, 38:145-165.

Hussong, D. M., and Fryer, P., 1982. Structure and tectonics of the Mariana arc and fore-arc: Drill site selection surveys. In Hussong, D. M., Uyeda, S., et al., Init. Repts. DSDP, 60: Washington (U.S. Govt. Printing Office), 33-34.

International Association of Geophysics and Aeronomy, 1976. International Geomagnetic Reference Field, 1975. R. Astron. Soc. Geophys. J., 44:733-734.

Jackson, E. D., and Schlanger, S. O., 1976. Regional synthesis, Line Islands chain, Tuamoto Island chain, and Manihiki Plateau, central Pacific Ocean. In Schlanger, S. O., Jackson, E. D., et al., Init. Repts. DSDP, 33: Washington (U.S. Govt. Printing Office), 915-927.

Kroenke, L. W., and Moberly, R., Jr., 1971. Lithologic interpretation of continuous reflection profiling. In Winterer, E. L., Riedel, W. R., et al., Init. Repts. DSDP, 7, Pt. 2: Washington (U.S. Govt. Printing Office), 1161-1174.

Lancelot, Y., and Larson, R. L., 1975. Sedimentary and tectonic evolution of the northwestern Pacific. In Larson, R. L., Moberly, R., et al., Init. Repts. DSDP, 32: Washington (U.S. Govt. Printing Office), 925-939.

Larson, R. L., 1976. Late Jurassic and Early Cretaceous evolution of the western central Pacific Ocean. Geomag. Geoelectr., 28:219-236.

Larson, R. L., and Chase, C. G., 1972. Late Mesozoic evolution of the western Pacific Ocean. Geol. Soc. Am. Bull., 83:3627-3644.

Larson, R. L., and Pitman, W. C., 1972. World-wide correlation of Mesozoic magnetic anomalies, and its implications. Geol. Soc. Am. Bull., 83:3645-3662.

Larson, R. L., Schlanger, S. O., et al., 1981. Site 462: Nauru Basin, western Pacific Ocean. In Larson, R. L., Schlanger, S. O., et al., Init. Repts. DSDP, 61: Washington (U.S. Govt. Printing Office), 19-397. 
Moberly, R., and Larson, R. L., 1975. Mesozoic magnetic anomalies, oceanic plateaus, and seamount chains in the northwestern Pacific Ocean. In Larson, R. L., Moberly, R., et al., Init. Repts. DSDP, 32: Washington (U.S. Govt. Printing Office), 945-957.

Orwig, T. L., and Kroenke, L. W., 1980. Tectonics of the eastern central Pacific basin. Mar. Geol. 34(1-2):29-43.

Raitt, R. W., 1954. Seismic refraction studies of Bikini and Kwajalein atolls. Prof. Pap. U.S. Geol. Surv., 260-K:507-527.

Schlanger, S. O., and Premoli Silva, I., 1981. Tectonic, volcanic, and paleogeographic implications of redeposited reef faunas of Late Cretaceous and Tertiary age from the Nauru Basin and the Line Islands. In Larson, R. L., Schlanger, S. O., et al., Init. Repts. DSDP, 61: Washington (U.S. Govt. Printing Office), 817-827.

Scripps Institution of Oceanography, 1968. Bathymetry Maps of the Pacific. $1.8^{\circ}$ /degree. Maps 1902, 1903, 2002, 2003, 2102, 2103, 2202, 2203.

Shipley, T. H., Whitman, J. M., Duennebier, F. K., and Petersen, L. D., 1983. Seismic stratigraphy and sedimentation history of the
East Mariana Basin, western Pacific. Earth Planet Sci. Lett., 64: 257-275.

Tamaki, K., Joshima, M., and Larson, R. L., 1979. Remanent Early Cretaceous spreading center in the central Pacific basin. J. Geophys. Res., 84:4501-4510.

Winterer, E. L., 1976. Anomalies in the tectonic evolution of the Pacific. In Sutton, G. H., Manghnani, M. H., and Moberly, R. (Eds.), The Geophysics of the Pacific Ocean Basin and Its Margin. Am. Geophys. Union Monogr., 19:269-278.

Winterer, E. L., Riedel, W. R., et al., 1971. Site 61. In Winterer, E. L., Riedel, W. R., et al., Init. Repts. DSDP, 7, Pt. 1: Washington (U.S. Govt. Printing Office), 27-35.

Date of Initial Receipt: 9 August 1984

Date of Acceptance: 11 January 1985

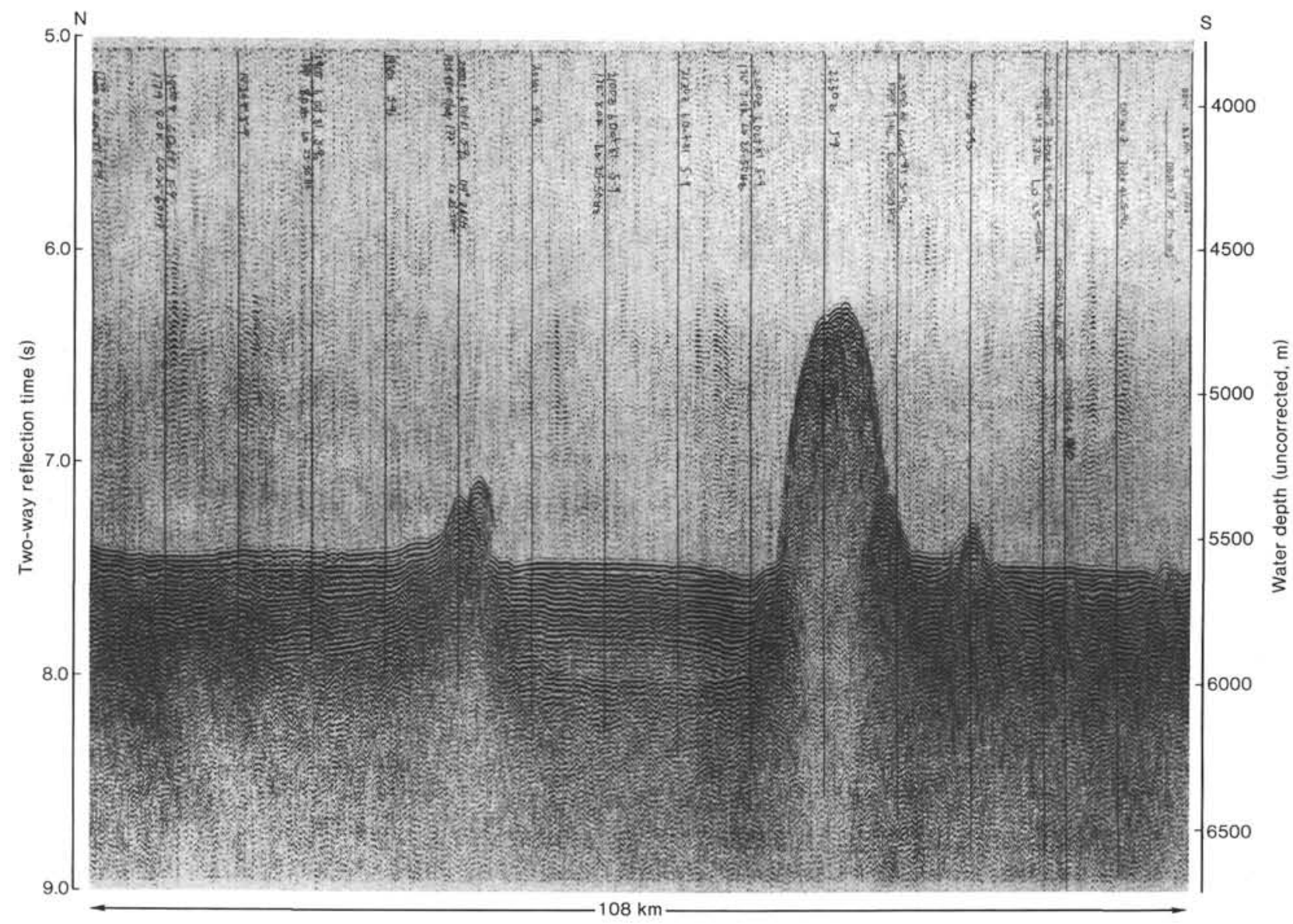

Figure 14. Seismic reflection profile from the low-frequency $(25-50 \mathrm{~Hz})$ recorder along track shown in Figure 13. Ridge relief, sediment thickness, and stratigraphy in the troughs vary throughout the MZP-3 region. 


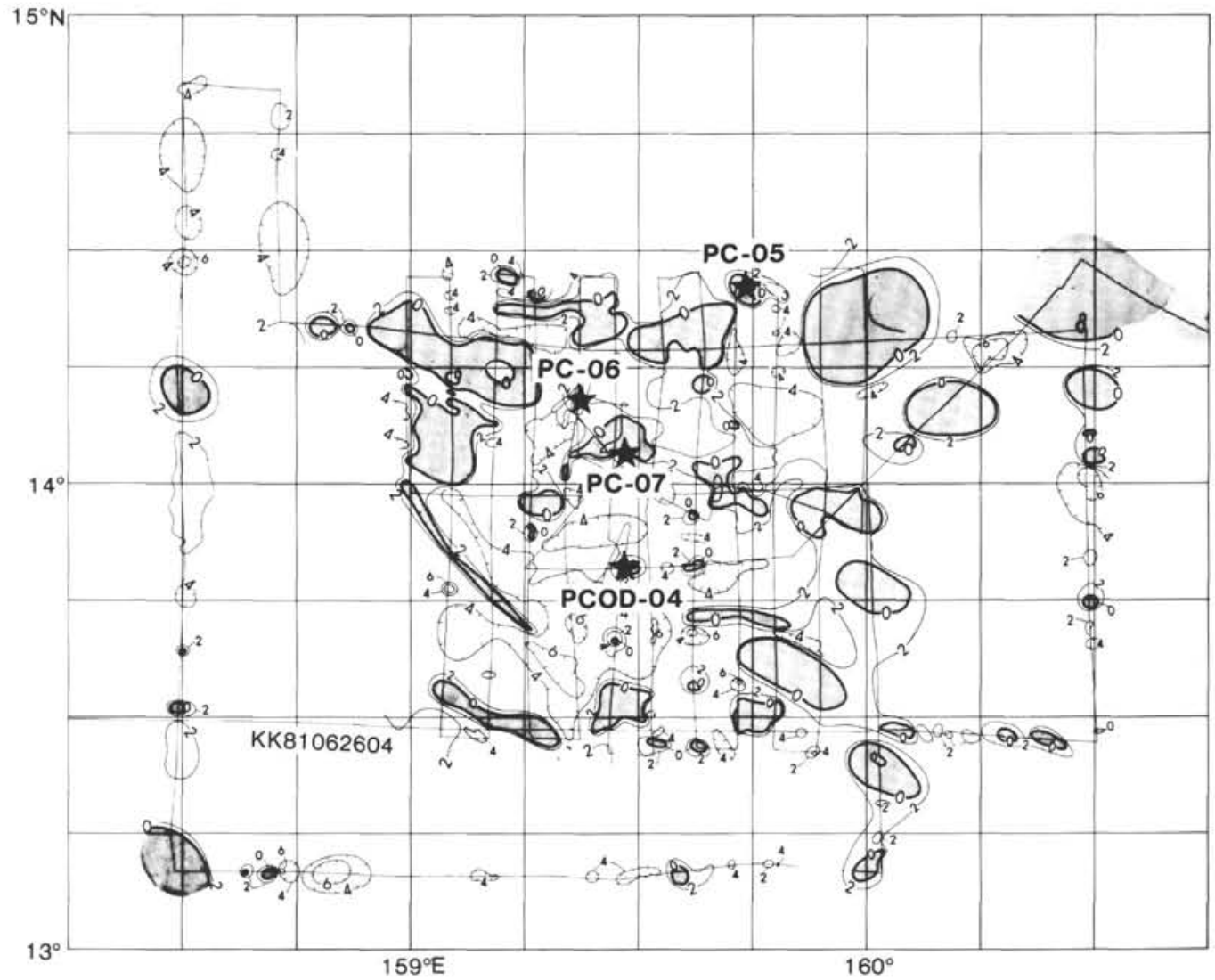

Figure 15. Thickness of transparent layer in the MZP-3 area, determined from KK810626 Leg $43.5-\mathrm{kHz}$ reflection records. Multiply values by 10 to get thickness in ms; contour interval $20 \mathrm{~ms}$. Shaded regions show areas of zero thickness. Locations of piston cores are shown by stars with core numbers. Ship tracks are shown as fine lines and identified by abbreviated cruise names and numbers. 


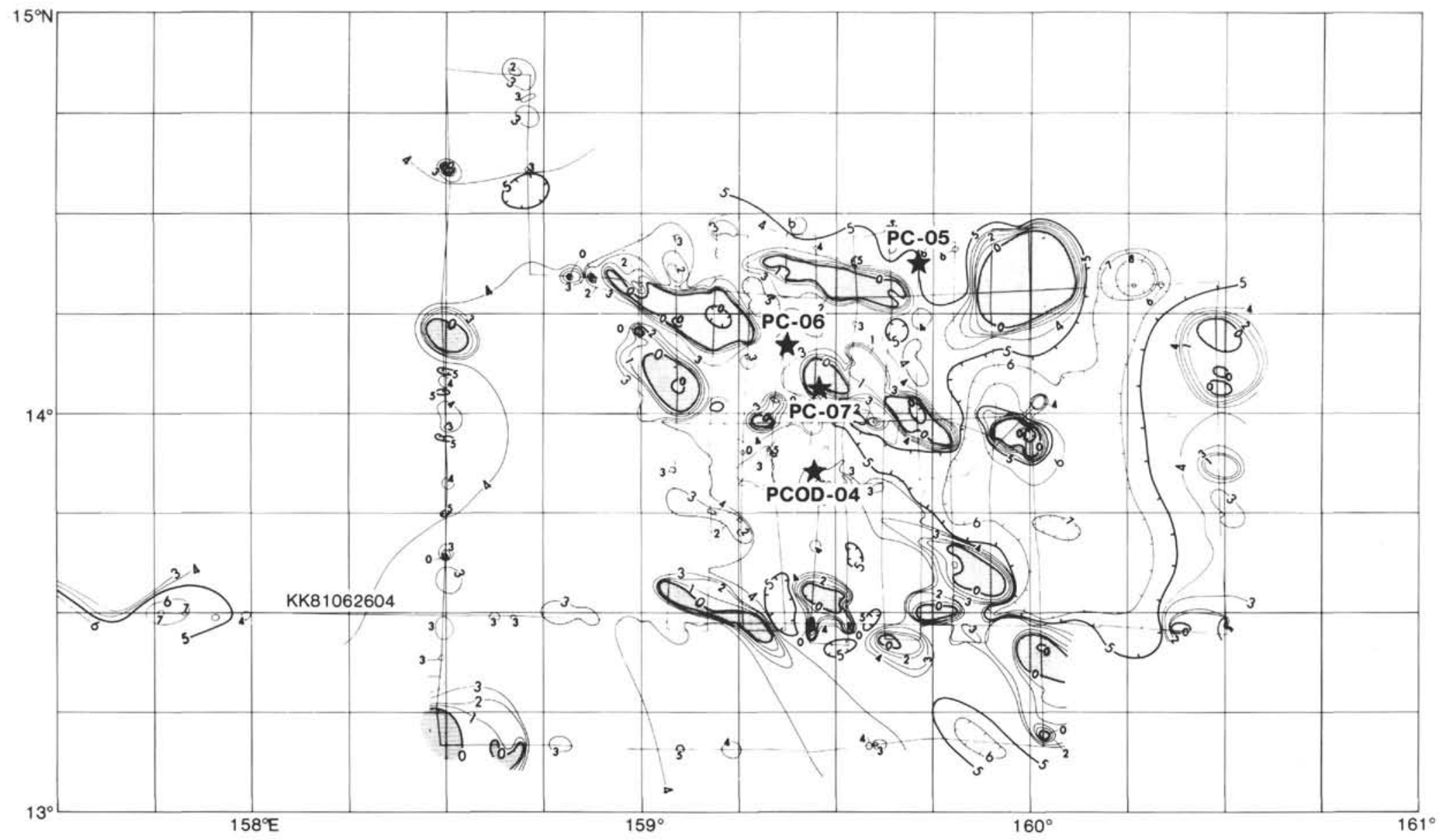

Figure 16. Total sediment thickness in the MZP-3 area, determined from KK810626 Leg 4 low-frequency reflection records. Multiply values by 100 to get thickness in ms; contour interval $100 \mathrm{~ms}$. Shaded regions indicate areas of zero thickness. Locations of piston cores are identified by stars with core numbers. Ship track is shown as a fine line and is identified by abbreviated cruise number. 


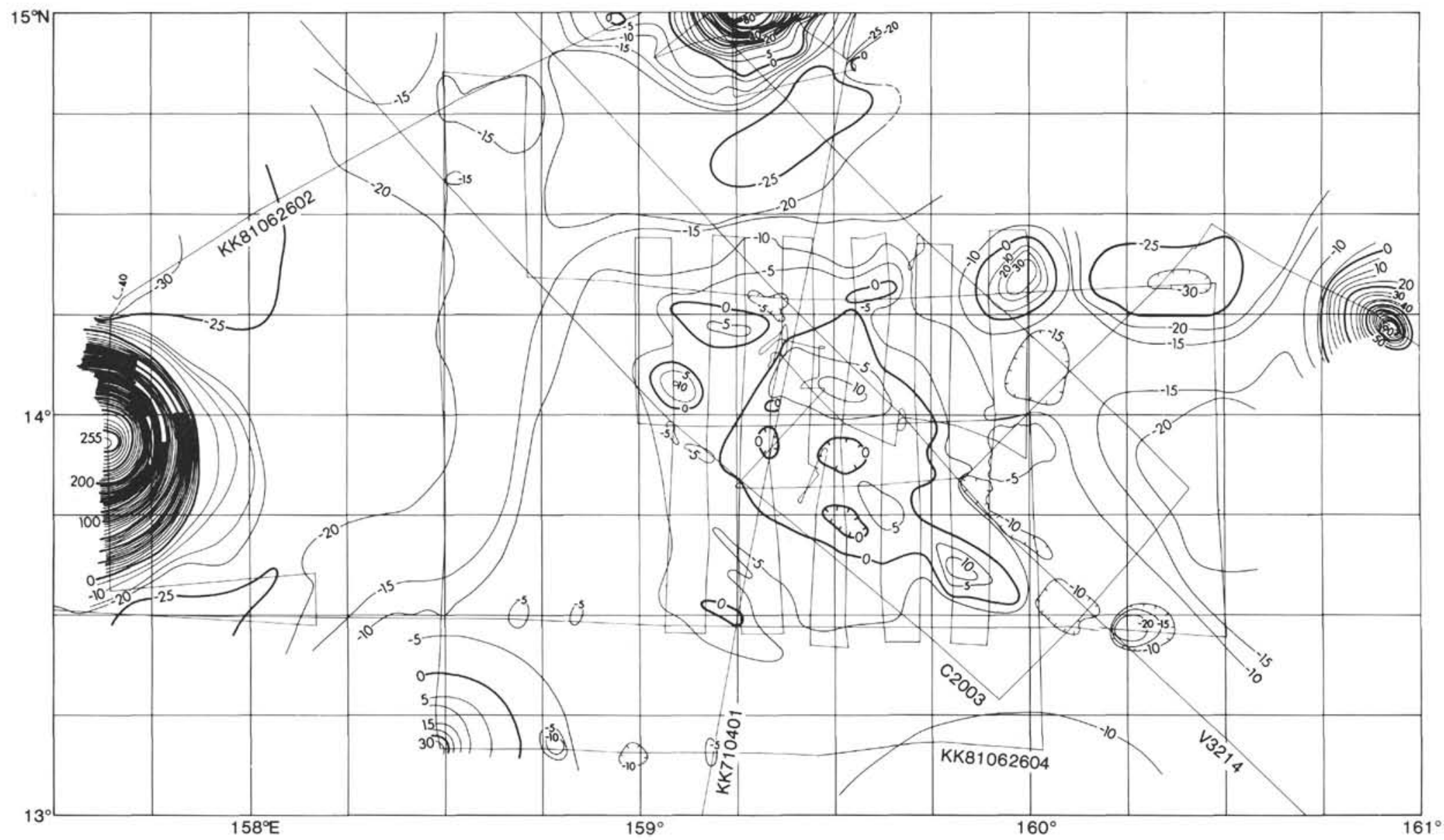

Figure 17. Free-air gravity contour map of the MZP-3 area. Values in mgal; contour interval $5 \mathrm{mgal}$. Ship tracks are shown as fine lines and identified by abbreviated cruise names and numbers. 


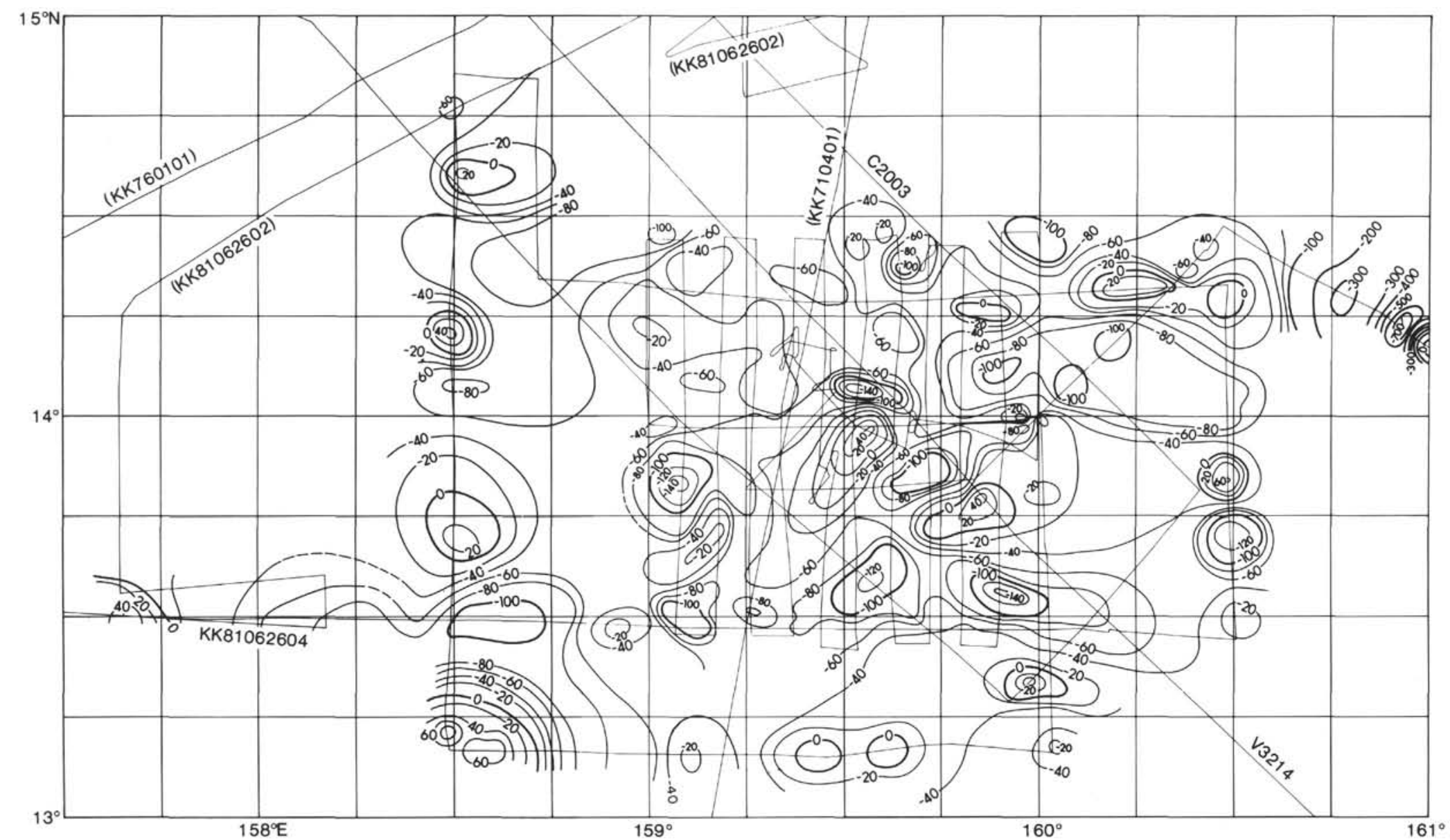

Figure 18. Residual-magnetism contour map of the MZP-3 region. Values in gammas; contour interval 20 gammas. Ship tracks are shown as fine lines and identified by abbreviated cruise names and numbers. Cruises from which data were not usable are identified by parentheses. 
Table 1. Average physical properties for cores in the MZP-3 area.

\begin{tabular}{|c|c|c|c|c|c|c|c|c|}
\hline Core & $\begin{array}{l}\text { Length } \\
(\mathrm{cm})\end{array}$ & $\begin{array}{l}\text { Lat. } \\
\text { (N) }\end{array}$ & $\begin{array}{c}\text { Long. } \\
\text { (E) }\end{array}$ & $\begin{array}{c}\text { Average } \\
\text { water } \\
\text { content } \\
(\%)\end{array}$ & $\begin{array}{l}\text { Average } \\
\text { density } \\
\left(\mathrm{g} / \mathrm{cm}^{3}\right)\end{array}$ & $\begin{array}{c}\text { Average } \\
\text { porosity } \\
(\%)\end{array}$ & $\begin{array}{c}\text { Average } \\
\text { grain } \\
\text { density } \\
\left(\mathrm{mg} / \mathrm{cm}^{3}\right)\end{array}$ & $\begin{array}{c}\text { Average } \\
\text { void } \\
\text { ratio }\end{array}$ \\
\hline PCOD-04 & 1227 & $13^{\circ} 49^{\prime} \mathrm{N}$ & $159^{\circ} 26^{\prime} \mathrm{E}$ & 65.37 & 1.24 & 83.00 & 2.49 & 5.03 \\
\hline PC-05 & 314 & $14^{\circ} 24^{\prime} \mathrm{N}$ & $159^{\circ} 43^{\prime} \mathrm{E}$ & 66.16 & 1.29 & 85.11 & 2.87 & 6.01 \\
\hline PC-06 & 973 & $14^{\circ} 11^{\prime} \mathrm{N}$ & $159^{\circ} 21^{\prime} \mathrm{E}$ & 64.48 & 1.24 & 83.25 & 2.63 & 5.15 \\
\hline PC-07 & 736 & $14^{\circ} 05^{\prime} \mathrm{N}$ & $159^{\circ} 27^{\prime} \mathrm{E}$ & 65.57 & 1.28 & 86.02 & 2.76 & 5.94 \\
\hline
\end{tabular}

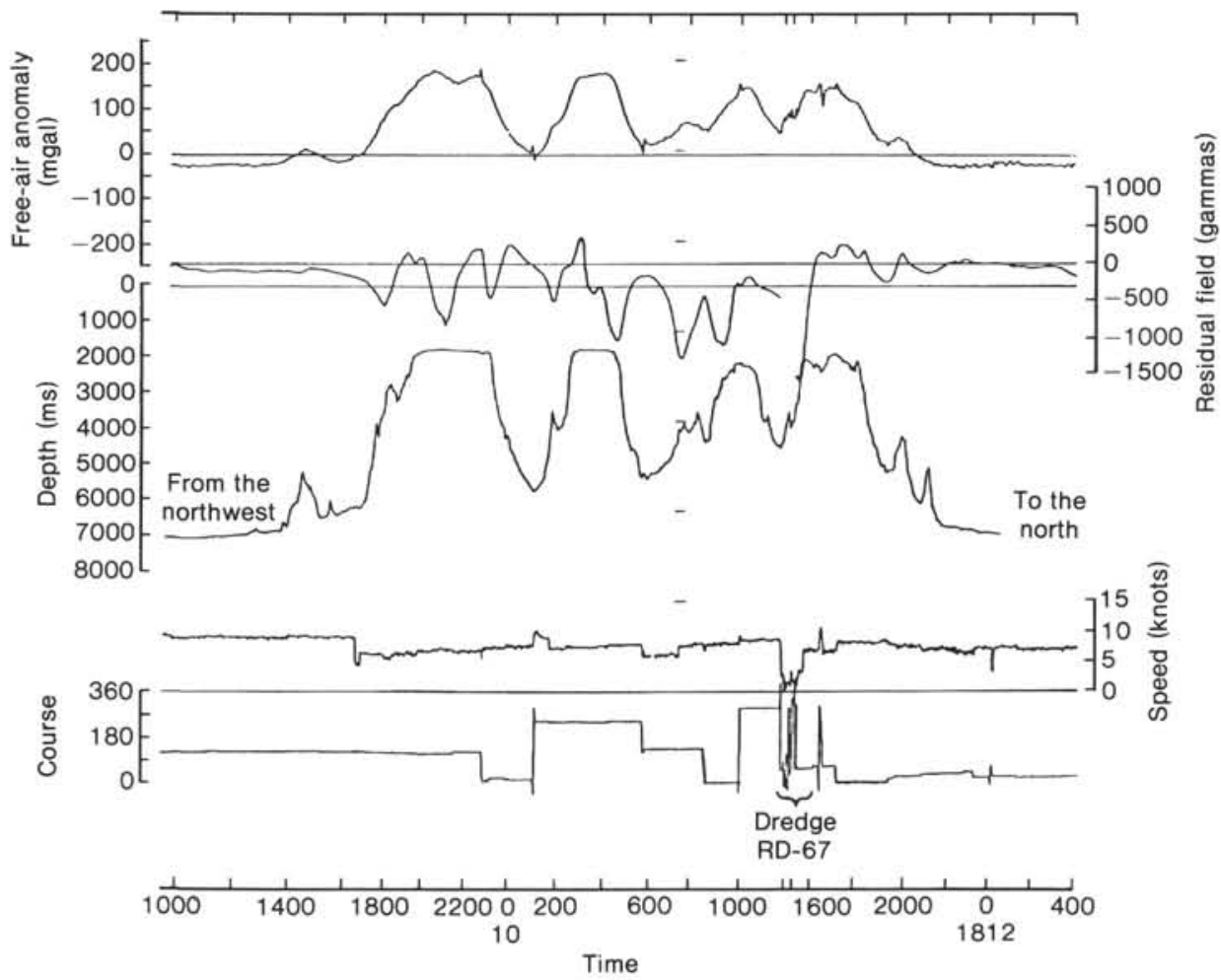

Figure 19. Underway geophysical data profiled along ship's track over Sylvania Guyot. 


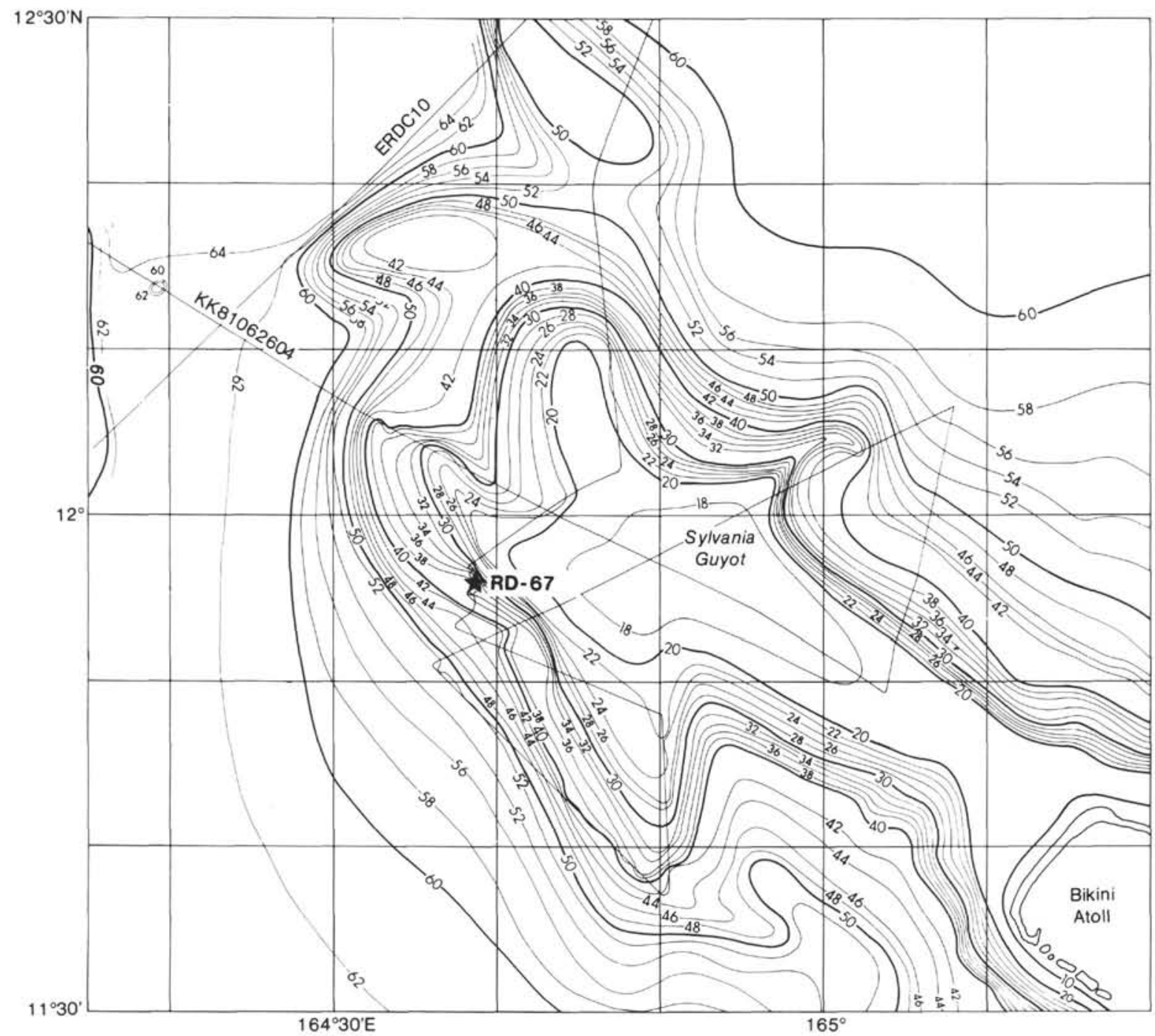

Figure 20. Bathymetry of Sylvania Seamount. Multiply values by 100 to get depth in ms; contour interval $200 \mathrm{~ms}$. Data from cruises (ship tracks shown as fine lines and identified by abbreviated cruise names and numbers) and bathymetric chart of Emery et al. (1954) make up data base for this map. Star shows location of dredge RD-67 on side of Sylvania; Bikini Atoll is at lower right. 


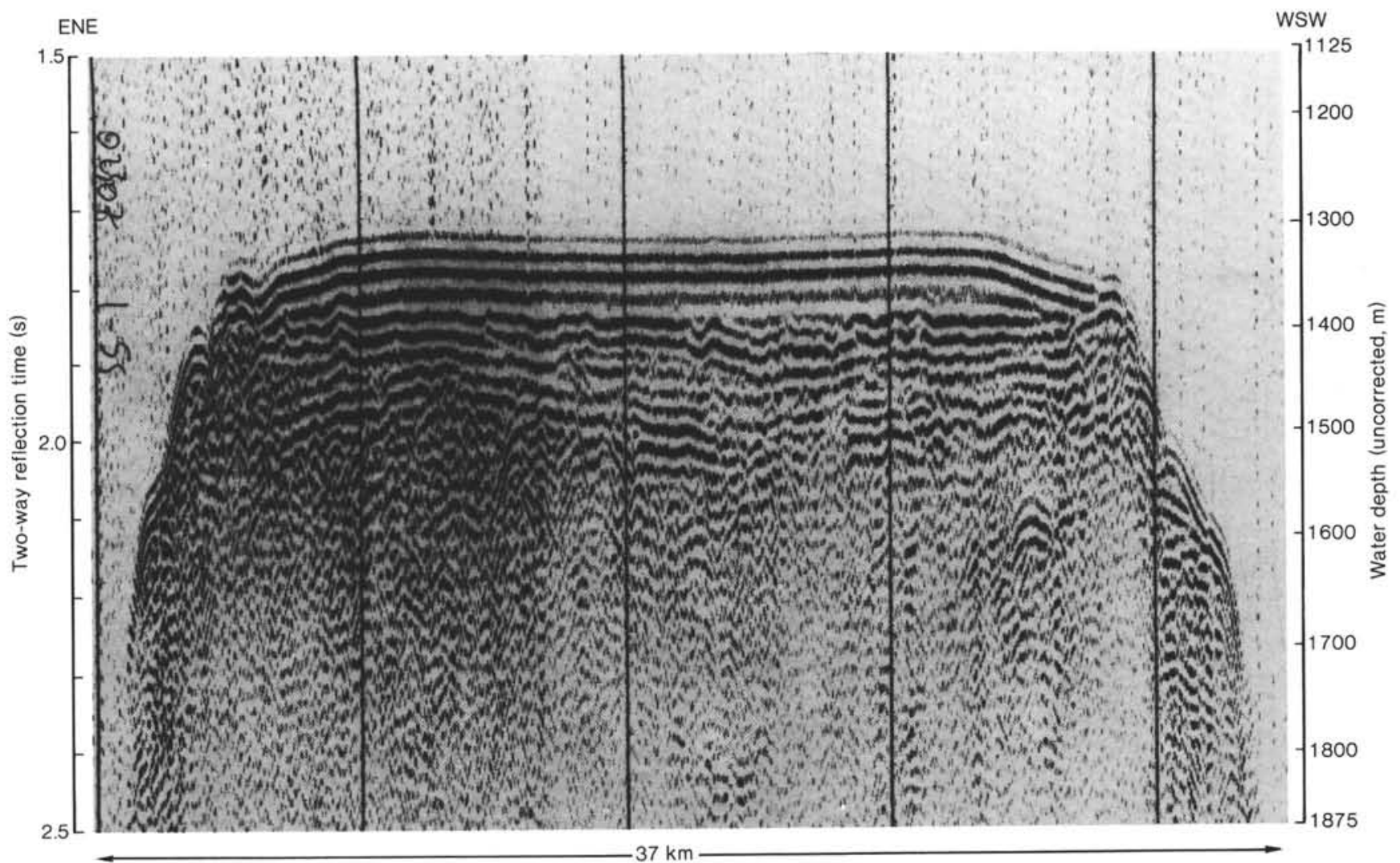

Figure 21. Seismic reflection profile along an ENE-WSW track across Sylvania Guyot, from the low-frequency $(25-50 \mathrm{~Hz})$ recorder. Pelagic ooze layer is about $110 \mathrm{~ms}$ thick, and overlies a reef cap approximately $190 \mathrm{~ms}$ thick. Dredge RD-67 was taken on the southwest slope of Sylvania near the right edge of this profile. 


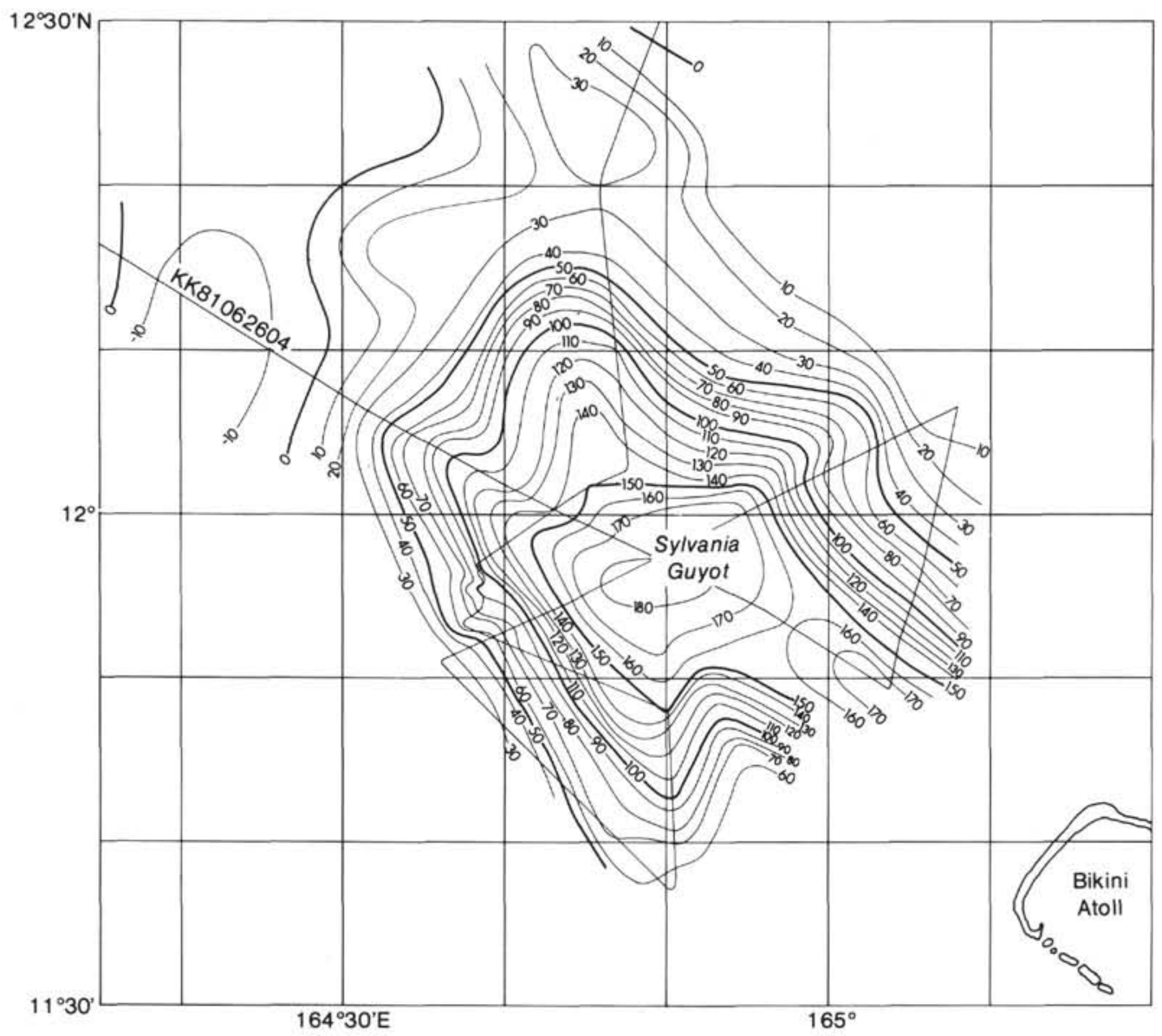

Figure 22. Free-air gravity contour map of Sylvania Seamount. Values are in mgal; contour intervals 10 mgal.

Only data from cruise KK810626 Leg 4 (track shown as fine line) were used to make this map.

A

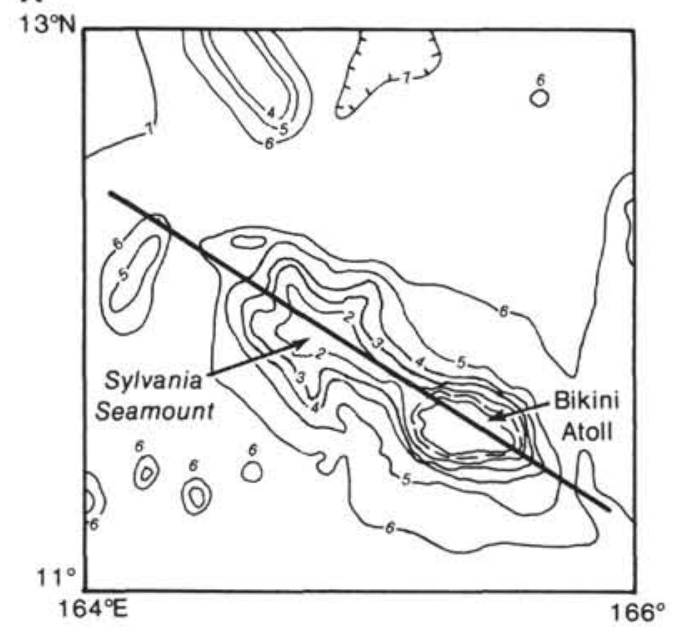

B

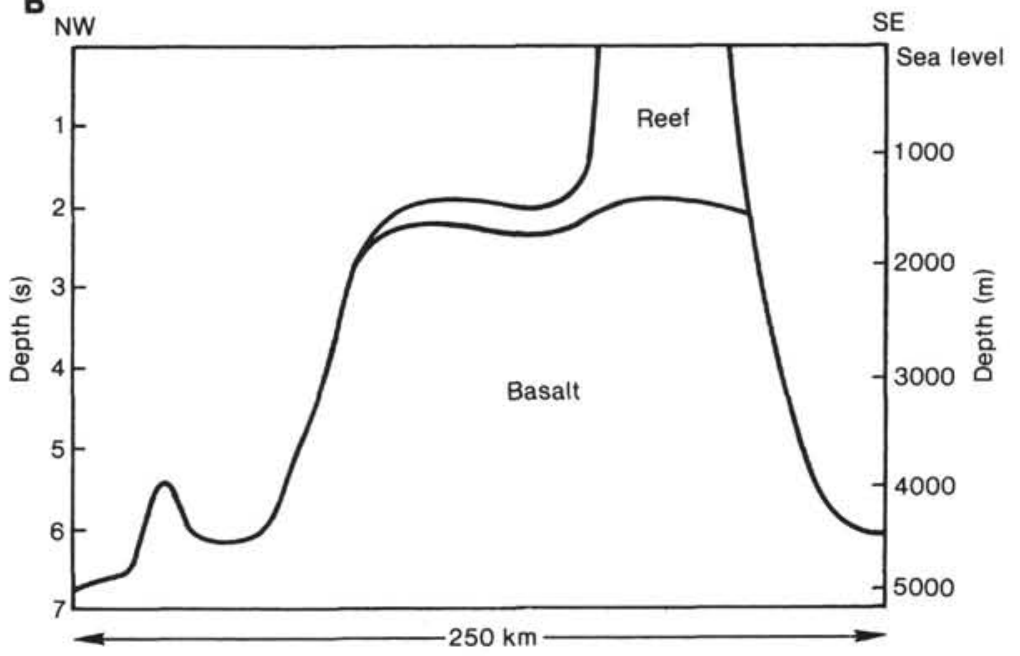

Figure 23. A. Sketch of bathymetry of Sylvania and Bikini. Contours are in seconds. Cross section along the NW-SE line is shown in (B). B. Cross section of Sylvania and Bikini along NW-SE line in (A). This shows the depth to volcanic basement is about the same at both Sylvania and Bikini, but the thickness of the reef cap is markedly different. 


\section{APPENDIX A \\ Cruise List}

The following cruises are known to have passed through the area bounded by $3-17^{\circ} \mathrm{N}$ and $140-180^{\circ} \mathrm{E}$. The numbers in the "Maps" column refer to the SIO Bathymetry maps (Scripps Institution of Oceanography, 1968): numbers 1 through 4 are SIO maps 2203N, 2103N, 2003N, and 1903N, respectively, and numbers 5 through 8 are SIO maps $2202 \mathrm{~N}, 2102 \mathrm{~N}, 2002 \mathrm{~N}$, and $1902 \mathrm{~N}$, respectively. Some cruise names have been abbreviated. Cruise data can be obtained through the National Geophysical Data Center (NGDC) in Boulder, Colorado.

\begin{tabular}{|c|c|c|c|c|c|c|c|c|c|c|c|c|c|}
\hline Cruises & Maps & Bath. & Mag. & Grav. & Year & Institution & Cruises & Maps & Bath. & Mag. & Grav. & Year & Institution \\
\hline ANTP13 & 1 & u & $t / r$ & - & 71 & SIO & KK8104 & $1,2,3,4,8$ & $u / c$ & $\mathrm{t} / \mathrm{r}$ & $d / f$ & 81 & HIG \\
\hline ANTP14 & $1,5,6$ & $\mathbf{u}$ & $t / r$ & - & 71 & SIO & KK8105 & 4,8 & $u / c$ & $t / r$ & $d / f$ & 81 & HIG \\
\hline BB21I & 1,5 & $u / c$ & $t / r$ & - & 72 & USN & MARA4 & 1 & $u / c$ & $t / r$ & - & 78 & SIO \\
\hline BB21J & 1,2 & $u / c$ & $t / r$ & - & 72 & USN & MC661000 & 7,8 & $u / c$ & - & - & 66 & HIG \\
\hline $\mathrm{Cl} 1007$ & $2,5,6$ & $u / c$ & $t / \tau$ & f & 66 & Lamont & MC661001 & 7,8 & $\dot{u} / \mathrm{c}$ & - & - & 66 & HIG \\
\hline C1107 & 1 & $u / c$ & $t / t$ & $f$ & 67 & Lamont & MC671000 & 7,8 & $\mathrm{u} / \mathrm{c}$ & - & - & 67 & HIG \\
\hline $\mathrm{C} 120 \mathrm{~s}$ & $2,6,7$ & $u / c$ & $t / r$ & f & 68 & Lamont & MH681000 & 8 & $u / c$ & $\mathrm{t} / \mathrm{r}$ & f & 68 & HIG \\
\hline $\mathrm{C} 1211$ & 8 & $\mathrm{u} / \mathrm{c}$ & $t / r$ & f & 68 & Lamont & $\mathrm{MH} 700403$ & $1,5,6$ & $u / c$ & $t / r$ & f & 70 & HIG \\
\hline $\mathrm{Cl} 304$ & 4,8 & $u / c$ & $t / r$ & - & 70 & Lamont & MH700404 & $1,5,6,7,8$ & $u / c$ & - & f & 70 & HIG \\
\hline $\mathrm{C} 1712$ & $1,2,4,6,7,8$ & $u / c$ & $t / r$ & f & 74 & Lamont & MH700405 & 1 & $\mathrm{u} / \mathrm{c}$ & - & f & 70 & HIG \\
\hline $\mathrm{C} 2003$ & $1,2,3$ & $\mathrm{u} / \mathrm{c}$ & $t / r$ & f & 76 & Lamont & NOVA01 & 4,8 & $\mathrm{u}$ & - & - & 67 & SIO \\
\hline $\mathrm{C} 2010$ & $1,2,4,6,7,8$ & $u / c$ & $t / r$ & - & 77 & Lamont & POL6202 & 1 & $\mathbf{u}$ & $\mathrm{t} / \mathrm{r}$ & f & 62 & NOAA \\
\hline $\mathrm{CIRCO2}$ & 1,2 & u & $t / r$ & - & 68 & S1O & PPIOI & $1,2,3,4$ & $u / c$ & - & $f$ & 64 & NOAA \\
\hline DDM05 & 2,7 & $u / c$ & - & $\mathrm{f}$ & 71 & Russian & SCANO4 & 1 & u & $t / r$ & - & 69 & SIO \\
\hline DDM06 & 2,7 & $u / c$ & - & f & 71 & Russian & SCANOS & $1,2,6,7,8$ & u & $\mathrm{t} / \mathrm{r}$ & - & 69 & SIO \\
\hline DDM09 & $1,2,6$ & $u / c$ & - & $f$ & & Russian & TSDY07 & 1 & u & $t / r$ & - & 73 & SIO \\
\hline DSDP07 & 8 & u & $t / r$ & - & 69 & SIO & TSDY08 & 1 & u & $t / r$ & - & 73 & SIO \\
\hline DSDP17 & 4,8 & u & $t / r$ & - & 71 & SIO & UM6503B & $3,4,8$ & c & $r$ & - & 66 & U Tokyc \\
\hline DSDP20 & $1,2,6,7$ & u & $t / r$ & - & 71 & SIO & UM67 & $1,2,5,6$ & c & $\mathbf{r}$ & - & $67-8$ & U Tokyo \\
\hline DSDP30 & $1,2,6$ & u & $t / r$ & - & 73 & S1O & V1907 & $1,2,6,7$ & $u / c$ & $t / r$ & f & 63 & Lamont \\
\hline DSDP31 & 1 & $\mathrm{u}$ & $\mathrm{t} / \mathrm{r}$ & - & 73 & SIO & V2108 & 1 & $u / c$ & $t / r$ & f & 65 & Lamont \\
\hline DSDP61 & $1,2,6,7,8$ & $\mathrm{u}$ & $t / r$ & - & 78 & SIO & V2404 & $3,4,8$ & $\mathrm{u}$ & $\mathrm{t}$ & f & 67 & Lamont \\
\hline DSDP62 & 4,8 & $u / c$ & $t / r$ & - & 78 & SIO & V2405 & $1,2,4,6,7,8$ & u & $t / r$ & f & 67 & Lamont \\
\hline ERDC07 & 1 & $\mathbf{u}$ & $t / r$ & - & 75 & SIO & V2811 & 8 & - & - & f & 71 & Lamont \\
\hline ERDC09 & $1,2,6,7,8$ & u & $t / r$ & - & 75 & SIO & V2813 & $1,5,6$ & $u / c$ & $t / r$ & f & 71 & Lamont \\
\hline ERDC10 & $3,4,7,8$ & $\mathbf{u}$ & - & - & 75 & SIO & V 2814 & 1,5 & $u / c$ & $t / r$ & f & 71 & Lamont \\
\hline GECSDMV & 4 & $\mathbf{u}$ & $t / r$ & - & 73 & SIO & V3214 & $2,3,7$ & $u / c$ & $t / r$ & f & 75 & Lamont \\
\hline GECSEMV & 8 & $\mathrm{u}$ & $t / r$ & - & 73 & SIO & V3401 & $1,2,3,7$ & $\mathrm{u} / \mathrm{c}$ & $t / r$ & f & 77 & Lamont \\
\hline IIOECGS & $1,2,3,4,5$ & c & $t / r$ & f & 64 & NOAA & V3506 & $1,2,6$ & $u / c$ & $t / r$ & f & 78 & Lamont \\
\hline INDP02 & 1 & u & $t / r$ & - & 76 & SIO & V3603 & 1,5 & $\mathrm{u} / \mathrm{c}$ & $t / r$ & f & 79 & Lamont \\
\hline INDP14 & $3,4,6,7$ & $\mathrm{u}$ & $t / r$ & - & 77 & SIO & V3610 & 7 & $u / c$ & $t / r$ & f & 80 & Lamont \\
\hline KH6705 & $1,2,5,6,7,8$ & c & $r$ & - & $67-8$ & U Tokyo & V3611 & $1,5,6$ & $u / c$ & $t / r$ & $f$ & 80 & Lamont \\
\hline KH6804D & 1 & c & $\mathrm{r}$ & f & 69 & U Tokyo & V3612 & 1 & $u / c$ & $t / r$ & f & 80 & Lamont \\
\hline KH7104 & $1,2,5,6$ & c & $r$ & f & 71 & U Tokyo & Data from the & lowing cruises w & not as & ilable : & of $9 / 82$ & & \\
\hline KK71040I & 2,6 & $u / c$ & $t / r$ & f & 71 & HIG & KK8103 & $1,2,6$ & $u / c$ & $t / r$ & $d / f$ & 81 & HIG \\
\hline KK710402 & 6 & $\mathrm{u} / \mathrm{c}$ & $t / t$ & $f$ & 71 & HIG & GH77-1 & $2,3,4,7,8$ & & & & 77 & (Japan) \\
\hline KK760101 & $1,2,3$ & $u / c$ & - & - & 76 & HIG & KH80-3 & $1,2,6$ & & & & 80 & (Japan) \\
\hline KK760102 & 1,2 & $u / c$ & $t / r$ & - & 76 & HIG & TOSHI M.15 & 1,5 & & & & 67 & (Japan) \\
\hline KK760103 & $1,5,6$ & $u / c$ & $t / r$ & $d / f$ & 76 & HIG & HAKUHO M. & $1,2,5,6,7$ & & & & 73 & (Japan) \\
\hline KK770301 & 8 & $u / c$ & $t / r$ & $d / f$ & 77 & HIG & BOSEI M. & 1,2 & & & & 73 & (Japan) \\
\hline KK 770302 & $6,7,8$ & $u / c$ & $t / r$ & $d / f$ & 77 & HIG & BOSEI M. & $1,2,6$ & & & & 72 & (Japan) \\
\hline KK 770303 & $1,2,6$ & $u / c$ & $t / r$ & $d / f$ & 77 & HIG & HAKUREI M. & & & & & 78 & (Japan) \\
\hline KK 770304 & 1 & $u / c$ & $t / r$ & $d / f$ & 77 & HIG & V3312 & 1 & & & & 76 & Lamont \\
\hline KK8102 & $2,3,4,6,8$ & $u / c$ & $t / r$ & $d / f$ & 81 & HIG & V3313 & & & & & 76 & Lamont \\
\hline
\end{tabular}

Note: $\mathrm{u}=$ uncorrected milliseconds; $\mathrm{t}=$ total magnetic field; $\mathrm{d}=$ gravim dial reading; $-=$ no data available; $\mathrm{c}=$ corrected $\mathrm{m} ; \mathrm{r}=$ residual magnetic field; $\mathrm{f}=$ free-air gravity; $\mathrm{HIC}$ = Hawaii Institute of Geophysics; NOAA = National Oceanic and Atmospheric Administration; SIO = Scripps Institution of Oceanography; USN = United States Navy; (Japan) = various Japanese agencies. 
APPENDIX B

Lithologic Descriptions of Cores

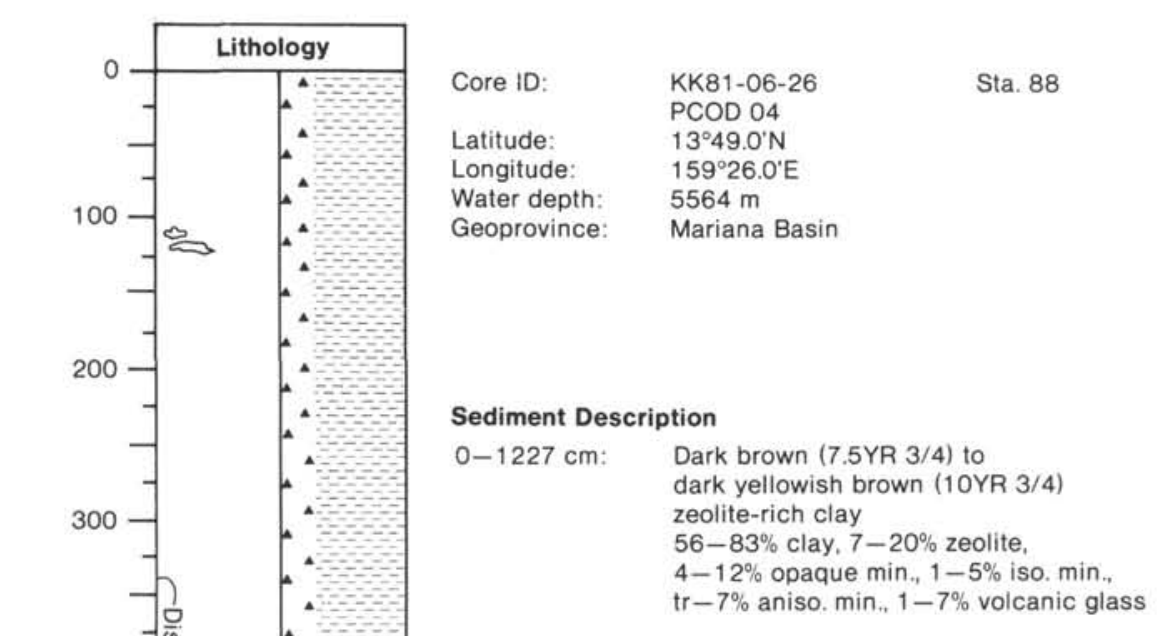

Mottling

Very slight to heavy mottling scattered sparsely throughout core; dark reddish brown to dark yellowish brown (5YR 3/2, 7.5YR 3/2, 4/6, 5/6, 10YR 4/4, 4/3).

533-537 cm: Void, airpocket

$544-546 \mathrm{~cm}$ : Semivoid

$588-607 \mathrm{~cm}$ : Sediment disturbed during opening

$620-633 \mathrm{~cm}$ : Semisoupy sediments 
Appendix B (continued).

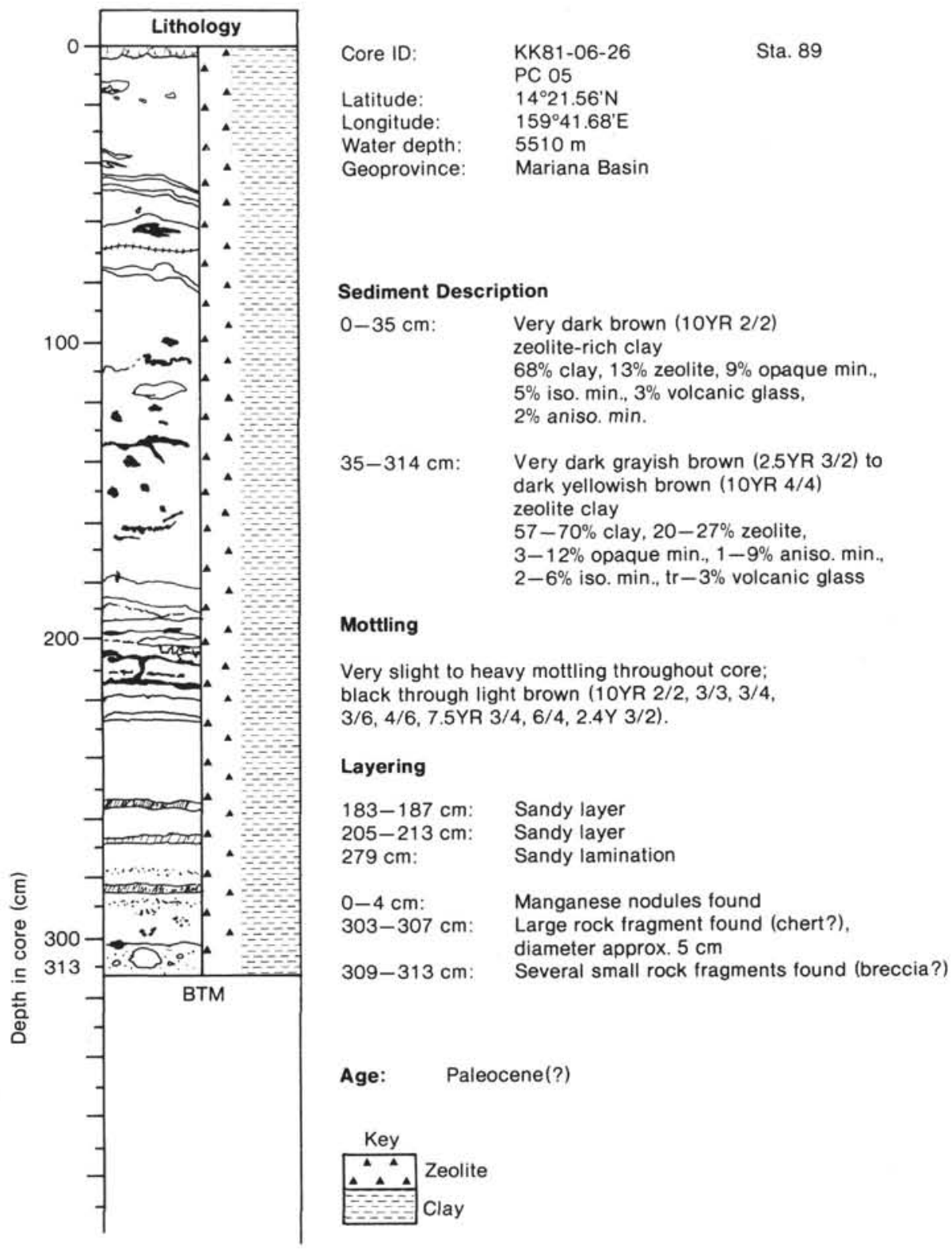


Appendix B (continued).

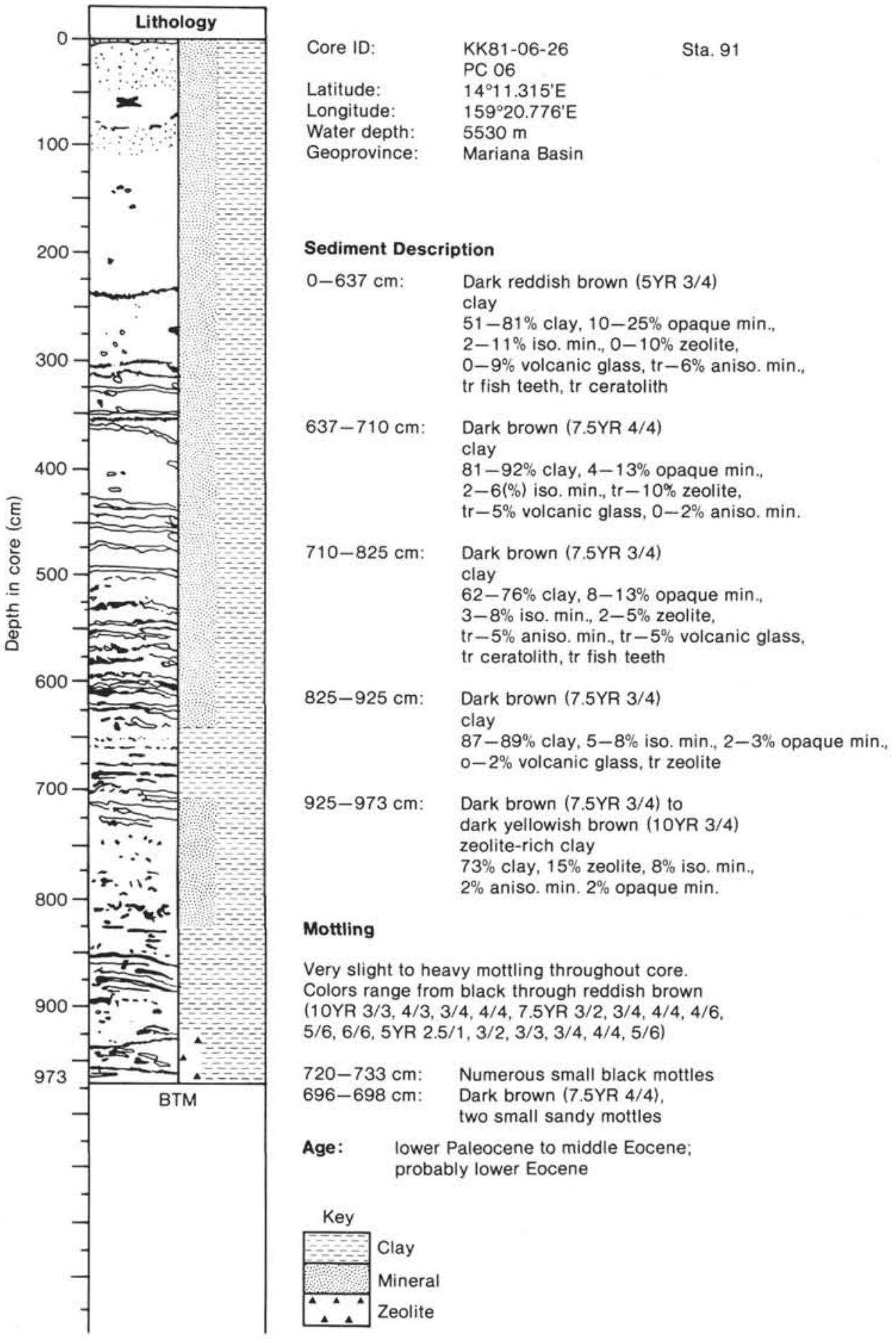


L. D. PETERSEN, F. K. DUENNEBIER, T. H. SHIPLEY

Appendix B (continued).

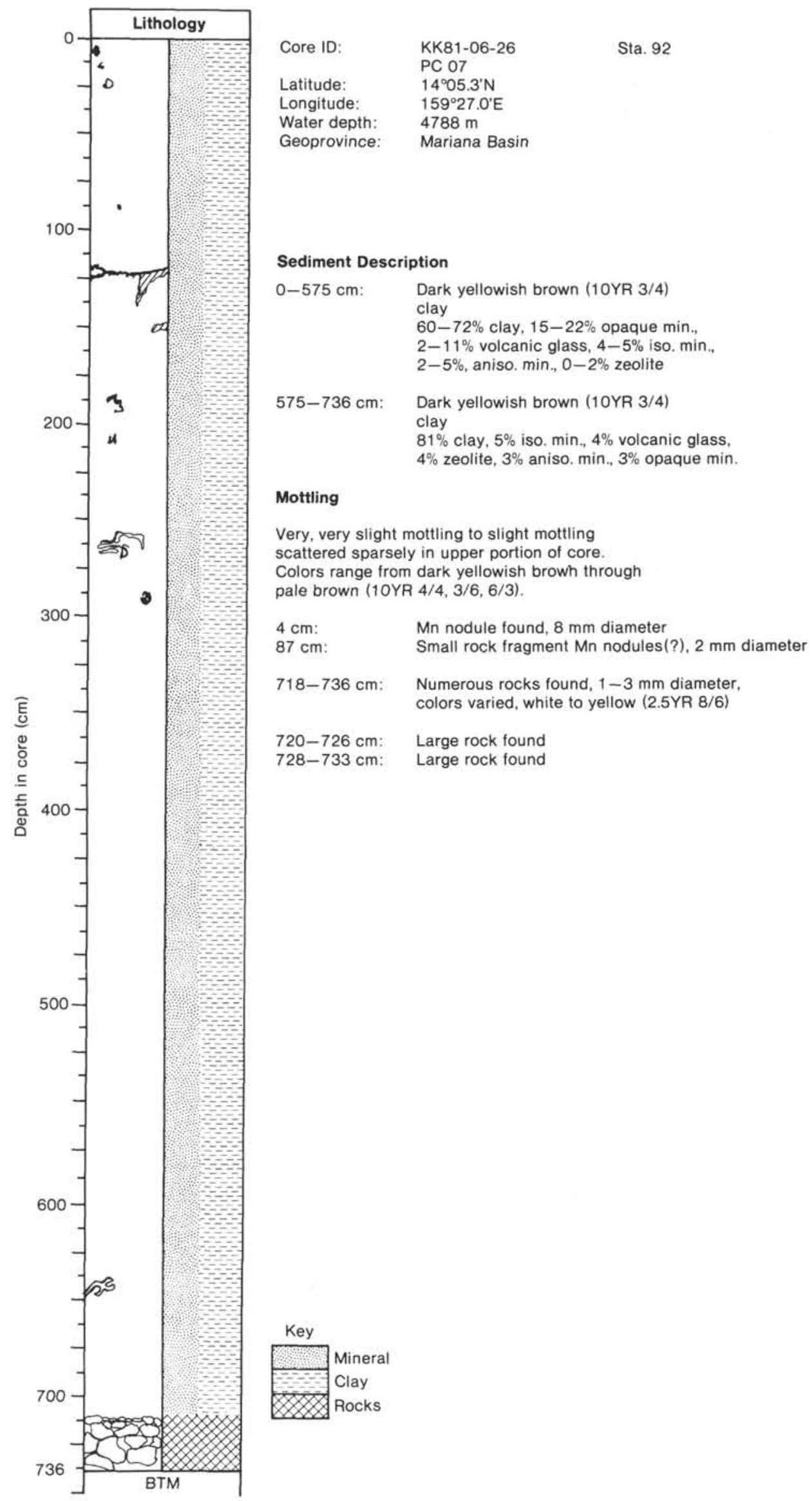

